8

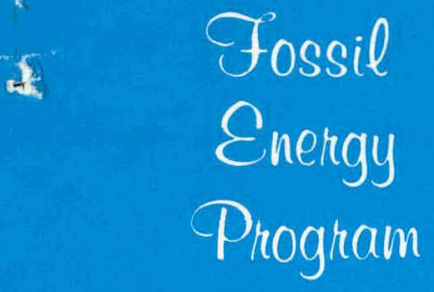

MASTER

Assessment of the State of the Art of Pressurized Fluidized Bed Combustion Systems
A. P. Fraas
R. L. Graves
M. E. Lackey 


\section{DISCLAIMER}

This report was prepared as an account of work sponsored by an agency of the United States Government. Neither the United States Government nor any agency Thereof, nor any of their employees, makes any warranty, express or implied, or assumes any legal liability or responsibility for the accuracy, completeness, or usefulness of any information, apparatus, product, or process disclosed, or represents that its use would not infringe privately owned rights. Reference herein to any specific commercial product, process, or service by trade name, trademark, manufacturer, or otherwise does not necessarily constitute or imply its endorsement, recommendation, or favoring by the United States Government or any agency thereof. The views and opinions of authors expressed herein do not necessarily state or reflect those of the United States Government or any agency thereof. 


\section{DISCLAIMER}

Portions of this document may be illegible in electronic image products. Images are produced from the best available original document. 


\section{Printed in the United States of America. Available from National Technical Information Service \\ U.S. Department of Commerce \\ 5285 Port Royal Road, Springfield, Virginia 22161 \\ Price: Printed Copy $\$ 5.25$; Microfiche $\$ 3.00$}

This report was prepared as an account of work sponsored by an agency of the United States Government. Neither the United States Government nor any agency thereof, nor any of their employees, contractors, subcontractors, or their employees, makes any warranty, express or implied, nor assumes any legal liability or responsibility for any third party's use or the results of such use of any information, apparatus, product or process disclosed in this report, nor represents that its use by such third party would not-infringe privately owned rights. 
ORNL/TM-6633

Contract No. W-7405-eng-26

Engineering Technology Division

\title{
ASSESSMENT OF THE STATE OF THE ART OF PRESSURIZED FLUIDIZED BED COMBUSTION SYSTEMS
}

Interim Report

\author{
A. P. Fraas \\ R. L. Graves \\ M. E. Lackey \\ Manuscript Completed - May 16, 1979 \\ Date Published - June 1979
}

Research sponsored by Tennessee Valley Authorlty under Inieragency Agreement TV-48296A under Union Carbide Corporation contract W-7405-eng-26 with the U.S. Department of Energy.

NOTICE: This document contains information of a preliminary nature. It is subject to revision or correction and therefore does not represent a final report.

Prepared by the OAK RIDGE NATIONAL LABORATORY Oak Ridge, Tennessee 37830 operated by UNION CARBIDE CORPORATION for the DEPARTMENT OF ENERGY

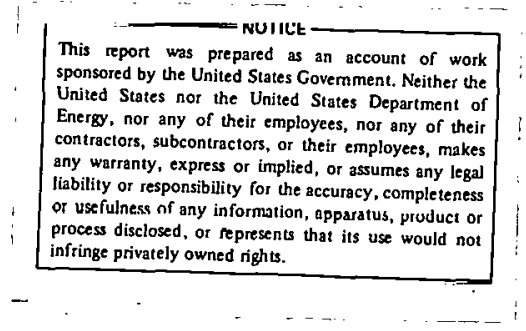

This report was prepared as an account of work United Sulese United States Government. Neither the ility or responsibility for the accuracy, completenes se any information, apparatus, 
THIS PAGE

\section{WAS INTENTIONALLY LEFT BLANK}




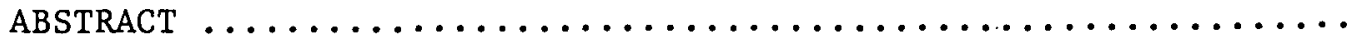

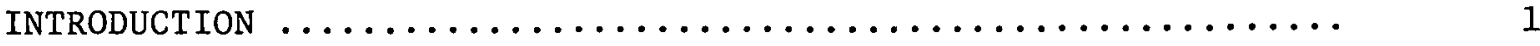

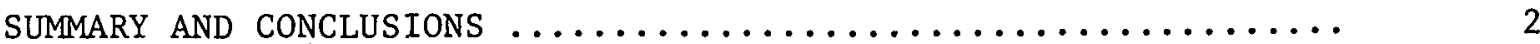

EVALUATIONS OF PFBC SYSTEMS FROM THE STANDPOINT OF DESIGN ADVANTAGES AND DISADVANTAGES, RELATIVE COSTS, AND HEAT RATES $\ldots$

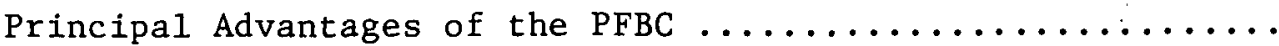

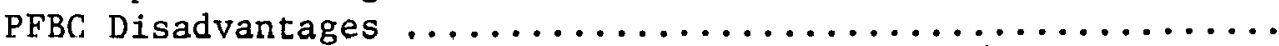

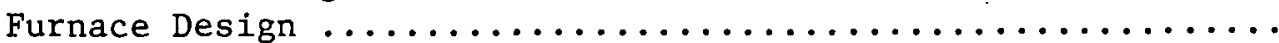

Comparison of Pulverized Coal-Fired and FBC Systems .......

SURVEY OF FACILITIES, PROGRAMS, AND EXPERIMENTAL RESULTS TO

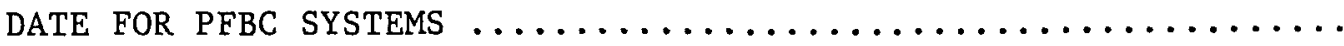

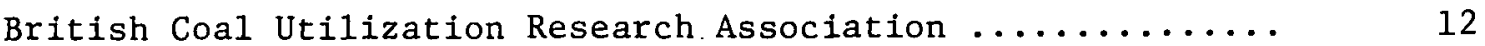

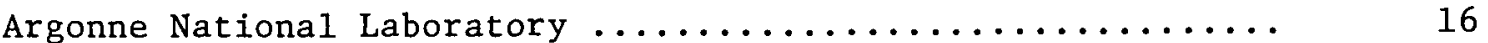

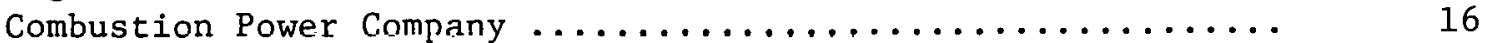

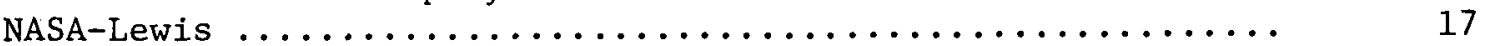

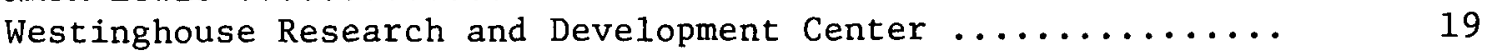

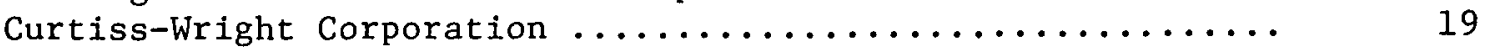

Grimethorpe Experimental Facility .................... 20

SURVEY OF TURBINE EROSION, CORROSION, AND DEPOSIT PROBLEMS ..... 21

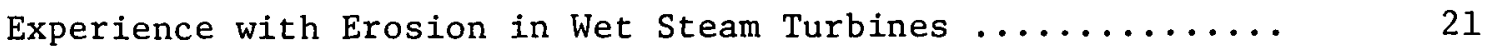

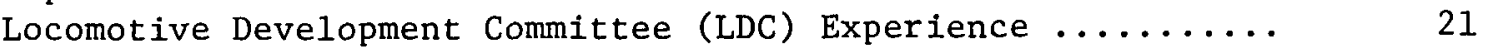

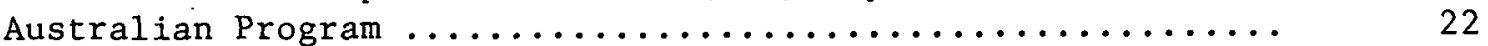

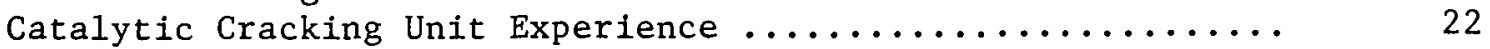

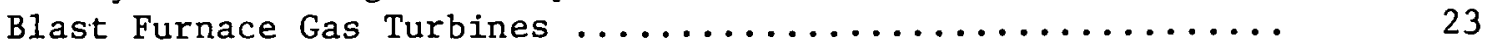

Air Filter Requirements for Commercial Gas Turbines ......... 24

Permissible Ash Content of Fuel Oils for Gas Turbines ........

Gas Turbines Used with Coal Gasification Plants ............ 24

Deposits in High Temperature Gas Turbines ............... 24

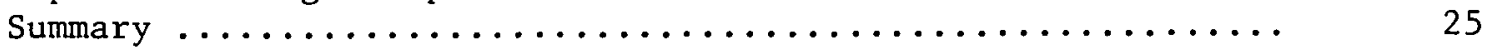

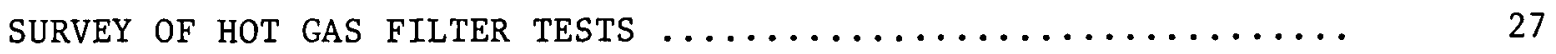

SURVEY OF DESIGN STUDIES FOR FULL-SCALE PFBC'S ............ 28

General Description of Power Plants ................ 28

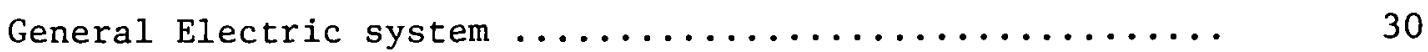

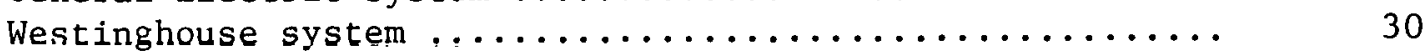

Burns \& Roe, United Technologies, and Babcock \& Wilcox ... 30

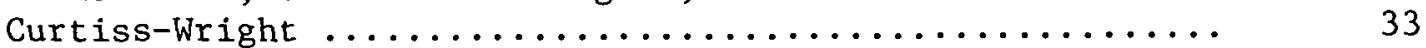

Oak Ridge National Laboratory ..................... 33 
$\underline{\text { Page }}$

Comparison of Selected Design and Performance Parameters .... 36

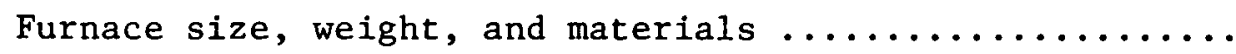

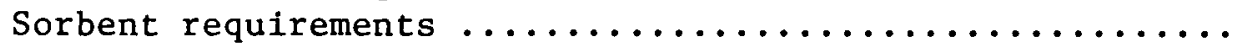

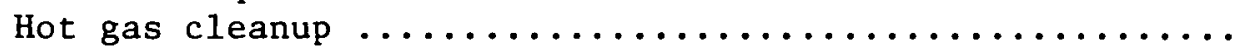

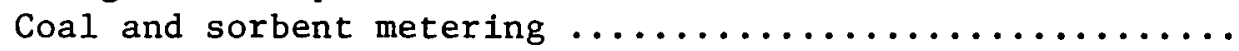

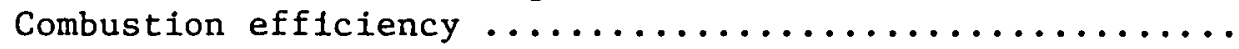

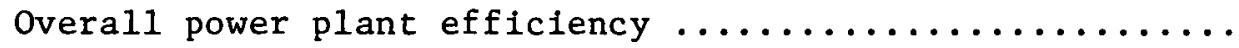

Estimates for plant cost and cost of electricity (COE) ...

Summary of design study survey $\ldots \ldots \ldots \ldots \ldots \ldots \ldots \ldots \ldots$

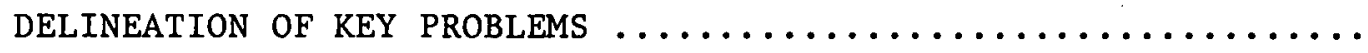

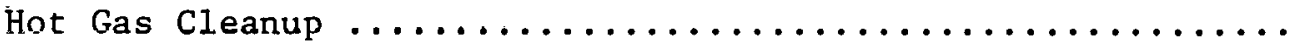

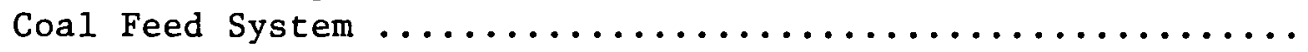

Lateral Rate of Coal Dispersion from Feed Points ...........

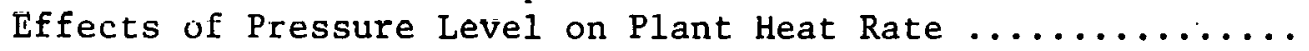

Effects of Bed Depth on the Performance of Presurized

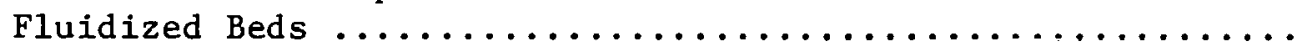




\section{ASSESSMENT OF THE STATE OF THE ART OF PRESSURIZED}

FLUIDIZED BED COMBUSTION SYSTEMS

Interim Report

A. P. Fraas, R. L. Graves, M. E. Lackey

\section{ABSTRACT}

This report was prepared at the request of the Tennessee Valley Authority (TVA) to clarify the development status of the pressurized fluidized bed combustor (PFBC) and to place in perspective the problems which are yet to be solved before commercialization of the concept is practical. The report is viewed as preliminary to a more complete and comprehensive work to be carried out during FY 1979.

An evaluation of the PFBC concept is included citing potential advantages over atmospheric pressure fluidized bed combustors (AFBC) in the areas of combustion efficiency, sulfur retention, furnace design, power plant efficiency, and others. The key disadvantage of unproven hot gas cleanup and associated gas turbine technology is discussed in considerable detail.

A survey of existing and developing PFBC experimental facilities is presented plus some results from the experimental programs. Recent design studies for full-sized PFBC power plants are reviewed with emphasis on key design parameters. Results for similar AFBC design studies are presented in contrast.

The general conclusion is drawn from this preliminary survey that the potential advantages of the PRBC used in conjunction with a high-temperature $\left[850^{\circ} \mathrm{C}\left(1560^{\circ} \mathrm{F}\right)\right]$ gas turbine will be difficult to realize due primarily to the formidable task of developing adequate hot gas cleanup and turbine systems, and due to the anticipated high cost of these systems.

\section{INTRODUCTION}

The problems of both atmospheric and pressurized fluidized beds are complex, and conflicting claims are prevalent. To help clarity the situation and give perspective to the concept, TVA has requested that Oak Ridge National Laboratory (ORNL) survey the status of the design and development of pressurized systems including the merits and developmental problems of these systems. As a first step in the program, it was requested that a preliminary scoping report be prepared surveying the work that has been 
done on pressurized fluidized beds, what can be expected from the more complete survey planned, and the degree of difficulty of the major problems.

Following the brief summary, the main body of this report begins with a general review of the PFBC, emphasizing its often cited advantages and disadvantages. This evaluation is followed by a survey of the development status of major components and of the concept itself. This survey covers experimental facilities and the results of experimental programs plus design studies of full-scale PFBC power plants. It is the purpose of this survey section to delineate the progress which has been and is being made toward realization of the predicted advantages of the PFBC and toward overcoming its apparent problems. The last section delineates the key problem areas requiring further developmental effort.

\section{SUMMARY AND CONCLUSIONS}

It has been generally assumed that there is a major advantage to pressurizing a fluidized bed coal combustion system because the furnace plan area and hence the number of coal feed points is essentially inversely proportional to the furnace pressure. Thus, to a first approximation, the size and cost of the furnase can he redired markedlyy by pressurizing the unit. However, the power required for compressing the air is so large that this can be accomplished economically only if the high-temperature, high-pressure combustion gases are used to drive a gas turbine which, in turn, drives the compressor that supplies the pressurized air to the furnace. The incorporation of the gas turbine provides an opportunity to increase the cycle efficiency by using a furnace pressure of $\sim 1.0 \mathrm{MPa}$ ( $10 \mathrm{~atm}$ ) with a combined gas turbine-steam cycle similar to that of over 200 'such units in operation in the U.S. employing oil or gas as fuel. However, the problems presented by turbine erosion and deposits if coal is used as fuel have made the development of such a system appear at least much more difficult than an atmospheric fluidized bed. The situation is quite complex with numerous other factors involved which have bearing on the attractiveness of the concept and the time and effort necessary for its development. 
Experimental programs have verified improvements in sulfur retention and combustion efficiency by increasing the fluidized bed combustor pressure. It is likely that a carbon burnup cell would not be necessary with the PFBC due to the higher combustion efficiency which is greatly attributable to the deeper bed of the PFBC.

In addition, the deeper bed permissible in the PFBC permits mounting the boiler tubes vertically. This allows the elimination from the bed of uncooled structure for supporting the boiler tubes and is a more compatible configuration in a cylindrical furnace shell. The deep bed and vertical tube arrangement have further advantages for start-up and control.

Despite its advantages, the PFBC is faced with several formidable obstacles to its development. Forty years of experience with removing particulate matter from hot gas streams. flowing into gas turbines indicates that the best that has been achieved with an economically viable system is to reduce the particulate content to around $100 \mathrm{ppm}$. However, for an acceptable turbine life, the particulate content must be kept below $1 \mathrm{ppm}$ if the turbine inlet temperature is to be in the 816 to $871^{\circ} \mathrm{C}$ $\left(1500\right.$ to $\left.1600^{\circ} \mathrm{F}\right)$ range as conceived in most of the recent design studies which propose bed pressures of $0.7-1.0 \mathrm{MPa}$ (7-10 atm). Both turbine bucket erosion and deposit problems become less serious as the turbine inlet temperature is reduced, and it appears that if the turbine inlet temperature is kept to $\sim 538^{\circ} \mathrm{C}\left(1000^{\circ} \mathrm{F}\right)$ a tolerable turbine life can be obtained with an inlet gas particulate content of $100 \mathrm{ppm}$. This is an indication that the development time and requirements for capital intensive equipment associated with hot gas cleanup may be lower for a PFBC of intermediate pressure, $0.3-0.5 \mathrm{MPa}$ (3-5 atm).

An additional serious obstacle to the development of the PFBC is that of feeding coal into a pressurized vessel. Solids feeding in general has not received sufficient attention in fluidized bed development programs and is often a source of trouble in experimental rigs. There is, of course, even less experience with PFBC coal feeders than with the AFBC feeders which are in a development stage themselves. Design studies have also indicated a high cost for PFBC solids feeding systems as currently envisioned. 
The four recent design studies with cost estimates reviewed in this report, in general, do not bear out all of the advantages of the PFBC which appear upon first inspection. Even with no monetary value placed on the development process and uncertainty in the performance of critical components, the PFBC, as concelved in these particular studies, is not universally seen as providing lower cost electricity. An advantage in fuel economy for the PFBC over conventional systems and the AFBC is concluded in all of the design studies but the incremental cost (mostly associated with gas cleanup equipment) is marginally justifiable. It should be noted that, at this time, a power system utilizing an intermediate pressure combustor has not been subjected to a rigorous analysis, design study, and cost estimate. Such an effort is recommended before any final conclusions are drawn on the PFBC system.

\section{EVALUATIONS OF PFBC SYSTEMS FROM THE STANDPOINT OF DESIGN ADVANTAGES AND DISADVANTAGES, RELATIVE COSTS, AND HEAT RATES}

It has been recognized for about 15 years that there is a major advantage to pressurizing a fluidized bed coal combustion system because the furnace size and hence the number of coal feed points is essentially inversely proportional to the furnace pressure. Thus, to a first approximation, the size and cost of the furnace can be reduced markedly by pressurizing the unit. However, the power required for compressing the air is so large that this can be accomplished economically only if the high temperature, high pressure combustion gases are used to drive a gas turbine which, in turn, drives the compressor that supplies the pressurized air to the furnace. The incorporation of the gas turbine provides an opportunity to increase the cycle efficiency by using a furnace pressure of $\sim 1.0 \mathrm{MPa}$ ( $10 \mathrm{~atm}$ ) with a combined gas turbine-steam cycle similar to that of over 200 such units in operation in the U.S. employing oil or gas as fuel. However, the problems presented by turbine erosion and deposits if coal is used as fuel have made such a system appear at least much more difficult to develop than an atmospheric fluidized bed. The situation is quite complex with numerous other 
factors being involved. This section presents a fairly comprehensive survey of the situation from the design and development standpoint to indicate the major boundary conditions and something of the quantitative value of the various advantages and disadvantages of the pressurized fluidized bed system as compared to the atmospheric fluidized bed.

\section{Principal Advantages of the PFBC}

The principal advantage of the pressurized fluidized bed stems from the fact that the maximum permissible combustion air velocity through the bed is determined by elutriation rates, which depend mainly on the superficial velocity of the combustion gas leaving the bed, essentially independent of the pressure. As a consequence, the maximum practicable mass flow of combustion air through the bed is directly proportional to pressure. Thus, both the furnace size and the number of feed points are essentially inversely proportional to the furnace pressure. Further, the depth of the bed that can be employed without experiencing excessive pumping power losses can be increased in direct proportion to the furnace pressure. A deep bed has the advantage that it gives a greater transit time for the fine coal particles passing through the bed if a bottom coal feed location is employed, and this in turn increases both the combustion efficiency and the sulfur retention. Note that in the Rivesville atmospheric fluidized bed, the bed depth is limited to about $1.2 \mathrm{~m}(4 \mathrm{ft})$. To increase the output per unit area of the bed, a high superficial gas velocity $[3.7 \mathrm{~m} / \mathrm{s}(12 \mathrm{ft} / \mathrm{sec})]$ is employed, and, as a consequence, about $25 \%$ of the carbon in the coal fed to the bed is blown out with the fines even with doubly screened coal.' To avoid a serious loss in the energy available from the coal, it is necessary to return the fines from the first-stage cyclone to a carbon burnup cell, and this must be operated at a temperature around $1093^{\circ} \mathrm{C}\left(2000^{\circ} \mathrm{F}\right)$ in order to burn the carbon in the high ash material. The high temperature leads to the formation of $\mathrm{NO}_{\mathrm{x}}$ to a much more serious degree than is the case for the main portion of the fluidized bed.

$\Lambda n$ important advantage of the deep beds in pressurized furnaces is that the boiler. tubes in the bed can be mounted vertically instead of 
horfzontally. This not only makes it possible to eliminate all uncooled structure for supporting the boiler tubes in the bed, which is advantageous from the corrosion standpoint, but it also makes it possible to employ a cylindrical furnace with a minimum of awkwardness in tube bundle configuration. Both of these factors tend to reduce the cost of the furnace shell and the tube matrix in the bed. Note, too, that the use of vertical tubes makes it possible to effect good water recirculation in the boiler tubes by natural thermal convection so that a boiler recirculating pump is not required.

The greater bed depth permissible if the furnace is pressurized has a number of subtle but important. advantages from the standpoint of control. The greater bed depth, for example, makes possible a larger space between the air tuyeres and the bottom of the boiler tube matrix, this gap being only a small fraction of the total bed depth at full power. The pumping power associated with such an increment in bed depth is small, while the gap improves mixing of the fuel and air before it reaches the heat transfer matrix so that it reduces the possibility for boiler tube corrosion arising from local regions in which a reducing atmosphere might prevail. Further, the use of a fairly generous plenum between the air tuyeres and coal feed points on the one hand and the bottom of the tube matrix on the other, makes it possible to start-up the fluidized bed with its level a little below the boiler tube matrix so that there would be no boiler tubes immersed in the bed under startup conditions, and hence, no large heat losses to these tubes. Further, with a fluidized bed depth of the order of $3.7 \mathrm{~m}(12 \mathrm{ft}$ ) at full power, the problems of sensing and controlling bed depth are eased because a few-inch change in bed depth represents a much smaller fraction of the total depth than for a typical atmospheric bed. Also, by using bed depth as the prime mechanism for controlling the boiler furnace output, one has a reasonably linear relationship between bed depth and furnace output because the amount of heat transfer surface area immersed in the bed is directly proportional to the bed depth above the bottom of the heat transfer matrix. The exposed tube matrix above the bed will remove some heat from the flue gas which in turn will reduce the flue 
gas turbine output. The combination of reduced bed heat transfer surface and reduced turbine output can be utilized as a plant load control mechanism.

\section{$\underline{\text { PFBC Disadvantages }}$}

In addition to the principal difficulty of turbine erosion, corrosion, and deposits (discussed in a later section), pressurizing a fluidized bed poses some very serious problems in feeding the coal into the bed against a relatively high furnace pressure. If an atmospheric bed is employed, the coal feed system needs to operate against a pressure of perhaps $0.014 \mathrm{MPa}$ ( $2 \mathrm{psig}$ ), but if the furnace is pressurized, the coal feed system must deliver the crushed coal against a pressure of 0.3 to $1.0 \mathrm{MPa}$ ( 3 to $10 \mathrm{~atm}$ ). This can be accomplished with lockhoppers, but these have proved to be a major source of mechanical troubles in every type of chemical process system in which they have been employed. Other methods of introducing granular solids through some sort of a pressure lock have all given substantial difficulties so that a major set of development problems must be overcome in the development of the coal feed system for pressurized fluidized beds.

Another important disadvantage of pressurized fluidized beds stems from the fact that there is considerably less operating experience with units of this type than with atmospheric fluidized bed coal combustion systems: It is not clear just how serious this disadvantage will prove to be, but it certainly is a factor in the thinking of many people involved.

The various advantages and disadvantages of pressurized fluidized beds cited above are summarized in Table 1 . Some of these factors involve considerations that merit further discussion.

\section{Furnace Design}

There are many subtle considerations in the design of the boiler furnace that are difficult to quantify. These include the problems of making a furnace shell sufficiently leak-tight so that combustion gas and fine ash do not percolate out into the surrounding area, the 
Table 1. Comparison of relatire advantages and disadvantages of atmospheric and pressurized flididized bed coal combustion systems

\begin{tabular}{|c|c|c|c|}
\hline $\begin{array}{l}\text { Furnace } \\
\text { pressure }\end{array}$ & $\begin{array}{l}\text { Atmospheric } \\
0.10 \mathrm{MPa} \mathrm{(1} \mathrm{atm)}\end{array}$ & $\begin{array}{c}\text { Pressurized } \\
0.3-0.5 \mathrm{MPa}(3-5 \mathrm{~atm})\end{array}$ & $\begin{array}{l}\text { Pressurized } \\
1.0 \mathrm{MPa}(10 \mathrm{~atm})\end{array}$ \\
\hline Advantages & $\begin{array}{l}\text { Fewest feastbility problems } \\
\text { Greatest anount of test ex- } \\
\text { perience } \\
\text { Coal feed against only } 0.014 \mathrm{MPa} \\
\text { ( } 2 \text { psi) } \\
\text { Solid wasta disposal much less } \\
\text { difficult than for wet scrubbers } \\
\text { Plant effiziency higher than for } \\
\text { wet scrubbers by } 1 \text { point } \\
\text { Capital cost modestly improved } \\
\text { over cenventional plant with } \\
\text { scrubb:rs }\end{array}$ & $\begin{array}{l}\text { Capital cost of furnace and } \\
\text { steam generation appears } \\
\text { lower than for conventional } \\
\text { pulverized coal unit } \\
\text { Coal feed points reduced by a } \\
\text { factor of } 3-5 \text { over AFB } \\
\text { Large bed depth improves com- } \\
\text { bined efficiency and } \mathrm{SO}_{2} \text { re- } \\
\text { moval and permits vertical } \\
\text { boiler tubes with simpler } \\
\text { furnace structure } \\
\text { Plant thermal efficiency about } \\
\text { l point higher than for AFB } \\
\text { Control characteristics appear } \\
\text { to be excellent }\end{array}$ & $\begin{array}{l}\text { Potential cycle thermal effi- } \\
\text { clency is about } 3.5 \text { points } \\
\text { higher than AFB } \\
\text { Capital cost of furnace and } \\
\text { steam generator appears } \\
\text { lower than for conventional } \\
\text { pulverized coal unit } \\
\text { Coal feed points reduced by } \\
\text { about a factor of } 10 \text { relative } \\
\text { to AFB } \\
\text { Large bed depth gives better } \\
\text { coal utilization and so } 2 \text { re- } \\
\text { moval as well as permitting } \\
\text { vertical tube array and } \\
\text { simpler furnace structure }\end{array}$ \\
\hline Disadvantages & $\begin{array}{l}\text { Large number of coal feed } \\
\text { points gives complex coal } \\
\text { feed system } \\
\text { Shallow beds require horizon- } \\
\text { tal tubes with support } \\
\text { structure at bed temperature } \\
\text { Startup and control problems } \\
\text { appear to be complex }\end{array}$ & $\begin{array}{l}\text { Feasibility of acceptable tur- } \\
\text { bine erosion and deposits } \\
\text { with } 538^{\circ} \mathrm{C}\left(1000^{\circ} \mathrm{F}\right) \text { turbine } \\
\text { inlet temperature seems likely } \\
\text { but has not yet been proven } \\
\text { Coal feed against } 0.3-0.5 \mathrm{MPa} \\
\text { ( } 3-5 \text { atm) poses difficult } \\
\text { reliability problems } \\
\text { Test experience much less than } \\
\text { for AFB }\end{array}$ & $\begin{array}{l}\text { Feasibility of acceptable tur- } \\
\text { bine erosion and deposit rates } \\
\text { is highly doubtful } \\
\text { Coal feed against } 1.0 \mathrm{MPa} \\
\text { (10 atm) poses difficult reli- } \\
\text { ability problems } \\
\text { Test. experience much less than } \\
\text { for AFB } \\
\text { Large heat capacity of granular } \\
\text { bed filters for hot gas cleanup } \\
\text { gives very slow response times } \\
\text { Particulate removal equipment } \\
\text { may entail excessive capital } \\
\text { cost }\end{array}$ \\
\hline
\end{tabular}


problems of retrofitting a new type of furnace to an existing plant, and floor space requirements.

Although not obvious, the pressure drop across an atmospheric fluidized bed is of the order of $0.015 \mathrm{MPa}$ (60 in.) of water. Thus, a potential problem exists in leakage of combustion gas and fly ash into the furnace room with conventional rectangular furnaces in which the joints between elements of the structure might be difficult to gasket. As a consequence, there is a major advantage to the use of a cylindrical shell that could be welded to give a simple leak-tight structure. It would be particularly desirable to make this shell so that the bulk of the gasketed flanged joints for access are located on the fresh combustion air side so that any leaks into the furnace room will be of clean air rather than combustion gas plus fine ash. Unfortunately, if an atmospheric fluidized bed is used, it is difficult to arrange the horizontal serpentine tubes required in a good cylindrical array; hence, one is almost required to employ a rectangular.furnace shell. If a pressurized fluidized bed is employed, the tubes can be mounted vertically which facilitates making the heat transfer matrix cylindrical with the boiler tubes suspended from support structure up in the freeboard over the bed. It is difficult to quantify this advantage, but a comparison of various designs for both pressurized and fluidized beds indicates that the cylindrical shell weighs substantially less and is substantially less complex to fabricate than a rectangular shell which requires extensive external bracing to carry the bending loads from the internal pressure on the large flat surfaces.

Furnace floor space requirements are an important factor in determining building size in a new plant and in the feasibility of retrofitting a fluidized bed boiler to an existing plant. Such retrofit projects may be quite important during the coming decades. The difficulties presented by the large cross-sectional area of atmospheric fluidized beds can be mitigated by stacking the beds one above the other. However, around $2.3 \mathrm{~m}$ ( $8 \mathrm{ft}$ ) of freeboard is required above each bed so that the overall height of the stacked beds for a given output is much greater than for a pressurized bed. Further, the cross-sectional area of the fluidized bed in such a 
stacked array is increased by the cross-sectional area required for the flow passages for flue gas and combustion air required by beds at higher or lower levels.

A major problem in the design of the fluidized bed furnaces is that the weight of material in the bed makes the structural design of the bed support grid progressively more difficult for bed diameters greater than about $4.6 \mathrm{~m}(15 \mathrm{ft})$ and for deeper beds. The structural weight tends to go up quite rapidly with bed diameter and depth because differential thermal expansion problems in the bed support grid structure make it necessary to employ a relatively small number of support points. Ihe bending loads in the unsupported span between these support points build up so that the weight of structure required tends to become excessive for bed diameters of more than about $10.7 \mathrm{~m}$ (35 $\mathrm{ft}$ ).

\section{Comparison of Pulverized Coal-Fired and FBC Systems}

Table 2 has been structured to facilitate a comparison of key parameters for the various conceptual designs for fluidized bed combustion systems with conventional pulverized coal plants that have been built and operated. Unfortunately, some of the data were not readily available and, hence, will have to be obtained at a later date. However, it is clear that the technology for fluidized bed combustor design is not yet sufficiently well in hand to provide a good basis for furnace designs. Differences in the number of coal feed points per unit of output are so large that the technological basis for choosing the number of coal feed points is clearly inadequate. Many other parameters reveal equal uncertainty.

\section{SURVEY OF FACILITIES, PROGRAMS, AND EXPERIMENTAL RESULTS TO DATE FOR PFBC SYSTEMS}

The combustion of coal in a pressurized fluidized bed has been investigated in small experimental units since the late 1960's. The earlier investigations were performed by the British Coal Utilization Research Association (BCUKA) and the Argonne National Laboratories (ANL). 
Table 2. Majo: design parameters for both typical pulverized coal-fired power plants and conceptual designs for fluidized bed combustion systems

\begin{tabular}{|c|c|c|c|c|c|c|c|c|c|c|c|}
\hline \multirow{2}{*}{ Plant } & \multicolumn{3}{|c|}{ Conventional pulverized coal } & \multicolumn{4}{|c|}{ Atmospheric fluldized bed } & \multirow{2}{*}{$\frac{\begin{array}{c}\text { Supercbarged } \\
\text { flu1d bed }\end{array}}{\therefore \text { orN }}$} & \multicolumn{3}{|c|}{ Pressurized fluld bed } \\
\hline & Bu11 Run & Colbert 175 & Kingston $\| 9$ & Rivesville & $\begin{array}{l}\text { Foster- } \\
\text { Wheeler }\end{array}$ & $\begin{array}{l}\text { Combustion } \\
\text { Engineering }\end{array}$ & $\begin{array}{l}\text { Babcock \& } \\
\text { W1lcox }\end{array}$ & & $\mathrm{GE}-\mathrm{ECAS}$ & $\begin{array}{l}\text { Westinghouse } \\
\text { ECAS }\end{array}$ & $\begin{array}{c}\text { Curtiss- } \\
\text { Wright }\end{array}$ \\
\hline $\begin{array}{l}\text { Design steam pressure and } \\
\text { teaperature, } \mathrm{MPa} /{ }^{\circ} \mathrm{C} /{ }^{\circ} \mathrm{C} \\
\left(\mathrm{ps}: \mathrm{Ig}_{\mathrm{g}} /{ }^{\circ} \mathrm{F} ;{ }^{\circ} \mathrm{O}\right)\end{array}$ & $\begin{array}{l}24 / 538 / 538 \\
(3500 / 1000 / \\
1300)\end{array}$ & $\begin{array}{l}17 / 566 / 538 \\
(2400 / 1050 / \\
1000)\end{array}$ & $\begin{array}{l}12 / 566 / 566 \\
(1800 / 1050 / \\
1050)\end{array}$ & $\begin{array}{l}9 / 496 / 538 \\
(1350 / 925 / \\
1000)\end{array}$ & $\begin{array}{l}26 / 540 / 540 \\
(3800 / 1005 / \\
1005)\end{array}$ & $\begin{array}{l}18 / 540 / 540 \\
(2600 / 1005 / \\
1005)\end{array}$ & $\begin{array}{l}18 / 539 / 539 \\
(2581 / 1003 / \\
1003)\end{array}$ & $\begin{array}{l}12 / 566 / 566 \\
(1800 / 1050 / \\
: 050)\end{array}$ & $\begin{array}{l}24 / 538 \\
(3515 / 1000) \\
.\end{array}$ & $\begin{array}{l}24 / 538 \\
(3515 / 1000)\end{array}$ & $\begin{array}{l}6 / 440 \\
(800 / 825)\end{array}$ \\
\hline Des.ign output, MW(e) & 85. & 550 & 200 & 30 & 150 & 200 & 200 & 200 & 904 & 679 & 500 \\
\hline $\begin{array}{l}\text { Overall plant thermal } \\
\text { eff fclency, } z\end{array}$ & 40 & 38.6 & 26.7 & & & & & & 39.2 & 39.0 & 38.8 \\
\hline Furnace arrangement & Conventional & Conventional & Conventional & $\begin{array}{l}\text { Single bed } \\
4 \text { compart- } \\
\text { ments }\end{array}$ & $\begin{array}{l}\text { Stacked } \\
4 \text { main } \\
1 \mathrm{CBC}\end{array}$ & $\begin{array}{l}\text { Ranch } \\
7 \text { ma1n } \\
1 \text { CBC }\end{array}$ & $\begin{array}{l}\text { Stacked } \\
4 \text { ma1n } \\
2 \mathrm{CBC}\end{array}$ & $\begin{array}{l}\text { Single bed } \\
\text { vertical } \\
\text { tubes }\end{array}$ & $\begin{array}{l}\text { Stacked } \\
7 \text { bed }\end{array}$ & $\begin{array}{l}\text { Stacked } \\
4 \text { bed }\end{array}$ & \\
\hline $\begin{array}{l}\text { Furnace pressure, MPa } \\
(\mathrm{atm})\end{array}$ & $\begin{array}{l}0.10 \\
(10\end{array}$ & $\begin{array}{l}0.10 \\
(1)\end{array}$ & $\begin{array}{l}0.10 \\
(1)\end{array}$ & $\begin{array}{l}0.10 \\
(1)\end{array}$ & $\begin{array}{l}0.10 \\
(1)\end{array}$ & $\begin{array}{l}0.10 \\
(1)\end{array}$ & $\begin{array}{l}0.10 \\
\text { (1) }\end{array}$ & $\begin{array}{l}0.30 \\
(j)\end{array}$ & $\begin{array}{l}1.0 \\
(10)\end{array}$ & $\begin{array}{l}1.0 \\
(10)\end{array}$ & $\begin{array}{l}0.7 \\
(7)\end{array}$ \\
\hline Surface area, $w^{2}\left(f t^{2}\right)$ & $\begin{array}{l}70.000 \\
(753,000)\end{array}$ & & $\begin{array}{l}20,500 \\
(221,000)\end{array}$ & & & $\begin{array}{l}22,000 \\
(237, \infty 00)\end{array}$ & & $\begin{array}{l}8,000 \\
(86,700)\end{array}$ & $\begin{array}{l}8,300 \\
(89,400)\end{array}$ & $\begin{array}{l}5,900 \\
(62,980)\end{array}$ & \\
\hline $\begin{array}{l}\text { Surface erea, } \mathrm{m}^{2} / \mathrm{MW}(\mathrm{e}) \\
{\left[\mathrm{ft}^{2} / \mathrm{MW}(\mathrm{e})\right]}\end{array}$ & $\begin{array}{l}82 \\
(836)\end{array}$ & & $\begin{array}{l}103 \\
(1,105)\end{array}$ & & & $\begin{array}{l}110 \\
(1,185)\end{array}$ & & $\begin{array}{l}40 \\
(434)\end{array}$ & $\stackrel{9}{(59)}$ & $\stackrel{9}{(93)}$ & \\
\hline $\begin{array}{l}\text { Furnace flan area, } \mathrm{m}^{2} / \mathrm{MW}(\mathrm{e}) \\
{\left[\mathrm{ft}^{2} / \mathrm{MW}(\epsilon)\right]}\end{array}$ & $\begin{array}{l}0.351 \\
(5.5)\end{array}$ & & $\begin{array}{l}0.052 \\
(5.6)\end{array}$ & $\begin{array}{l}0.14 \\
(1.52)\end{array}$ & $\begin{array}{l}0.97 \\
(10.4)\end{array}$ & $\begin{array}{l}1.24 \\
(13.4)\end{array}$ & $\begin{array}{l}1.80 \\
(19.4)\end{array}$ & $\begin{array}{l}0.632 \\
(6.8)\end{array}$ & $\begin{array}{l}0.055 \\
(0.59)\end{array}$ & $\begin{array}{l}0.17 \\
(1.85)\end{array}$ & \\
\hline $\begin{array}{l}\text { Heat transfer surface } \\
\text { welght, } \mathrm{kg}(1 \mathrm{~b})\end{array}$ & & $\begin{array}{l}2,270,000 \\
(5,000,000)\end{array}$ & $\begin{array}{l}1,000,000 \\
(2,200,000)\end{array}$ & & & & & $\begin{array}{l}404,500 \\
(890, \infty 00)\end{array}$ & & & \\
\hline $\begin{array}{l}\text { Total furnace we1ght. } \\
\text { kg (1b) }\end{array}$ & $\begin{array}{l}10 ; 900,000 \\
(2 i, 000,000)\end{array}$ & & $\begin{array}{l}3,800,000 \\
(8,400,000)\end{array}$ & & & & & & $\begin{array}{l}1,825,000 \\
(4,016,000)\end{array}$ & & \\
\hline $\begin{array}{l}\text { Heat transfer surface } \\
\text { weight, } \mathrm{kg} / \mathrm{MW}(\mathrm{e})[\mathrm{bb} / \mathrm{MW}(\epsilon)]\end{array}$ & & $\begin{array}{l}4,140 \\
(9,100)\end{array}$ & $\begin{array}{l}5,000 \\
(11,000)\end{array}$ & & & & & $\begin{array}{l}2,000 \\
(4,450)\end{array}$ & & & \\
\hline $\begin{array}{l}\text { Total furnace we1ght, } \\
\text { kg/MW (e) }[1 \mathrm{~b} / \mathrm{MW}(\mathrm{e})]\end{array}$ & $\begin{array}{l}12,800 \\
(23,230)\end{array}$ & & $\begin{array}{l}19,000 \\
(42,000)\end{array}$ & & & & & . & $\begin{array}{l}2,000 \\
(4,400)\end{array}$ & $\begin{array}{l}1,872 \\
(4,120)\end{array}$ & \\
\hline $\begin{array}{l}\text { Number of burners or } \\
\text { fuel feed points }\end{array}$ & 175 & & 56 & 44 & 16 & 118 & 640 & 144 & 335 & 64 & \\
\hline $\begin{array}{l}\text { Number of burners or fuel } \\
\text { feed points } / 100 \mathrm{MH}(\mathrm{e})\end{array}$ & 21 & & 28 & 147 & 11 & 59 & 320 & 72 & 37 & 9.4 & \\
\hline
\end{tabular}


These experimenters were later joined by groups at Combustion Power Company, Exxon Research and Engineering Company, NASA-Lewis Research Center, and Curtiss-Wright Corporation (Power Systems Division).

\section{British Coal Utilization Research Association}

The British Coal Utilization Research Association, Ltd. (BCURA), began a serles of pressurized fluidized bed coal combustion experiments in 1969.1-3 The experiments have proceeded in essentially three phases. The initial work was performed to obtain data on the emission of sulfur and nitrogen oxides and the effects of the fluidized bed environment upon boiler metal and turbine blade specimens when operating at absolute pressures of $0.35-0.6 \mathrm{MPa}(3.5-6 \mathrm{~atm})$ and temperatures in the range of $800^{\circ} \mathrm{C}\left(1470^{\circ} \mathrm{F}\right)$. The second phase involved an investigation of the bed operating characteristics at temperatures of 900 to $950^{\circ} \mathrm{C}$ (1650 to $1740^{\circ} \mathrm{F}$ ) at an absolute pressure of approximately $0.6 \mathrm{MPa}$ (6 atm). This phase of the work was completed in 1973.

A bed depth of approximately $1.2 \mathrm{~m} \mathrm{(4ft)}$ was employed during the first two series of experiments. For the third experimental series, the bed depth was increased to $2.4 \mathrm{~m}(7.9 \mathrm{ft})$. The system was operated at an absolute pressure of approximately $0.6 \mathrm{MPa}$ (6 atm) and a temperature of $870^{\circ} \mathrm{C}\left(1600^{\circ} \mathrm{F}\right)$.

The fluidizing velocity was maintained at approximately $0.6 \mathrm{~m} / \mathrm{s}$ (2 ft/sec) during the experimental series. The influence on the performance of the fluidized bed of the bed temperature, the $\mathrm{Ca} / \mathrm{S}$ ratio, and the bed depth were the major parameters investigated during the experimental series. Future experimental work is planned to investigate the effects of superficial velocity on the bed operation.

Figure 1 shows the effects of varying the $\mathrm{Ca} / \mathrm{S}$ ratio upon the sulfur retention by the bed for both dolomite and 1imestone. Shown in Figure 2 are effects of bed temperature on the sulfur retention at a constant $\mathrm{Ca} / \mathrm{S}$ ratio of 2 . The combustion efficiency of the pressurized combustion at a fluidizing velocity of $0.75 \mathrm{~m} / \mathrm{s}(2.5 \mathrm{ft} / \mathrm{sec})$ is in the 97.5 to $99.5 \%$ range as shown in Figure 3. Preliminary experiments at a fluidizing velocity of $2.1 \mathrm{~m} / \mathrm{s}(6.9 \mathrm{ft} / \mathrm{sec})$ at a temperature of $986^{\circ} \mathrm{C}\left(1645^{\circ} \mathrm{F}\right)$ 
ORNL-DWG 78-18915R

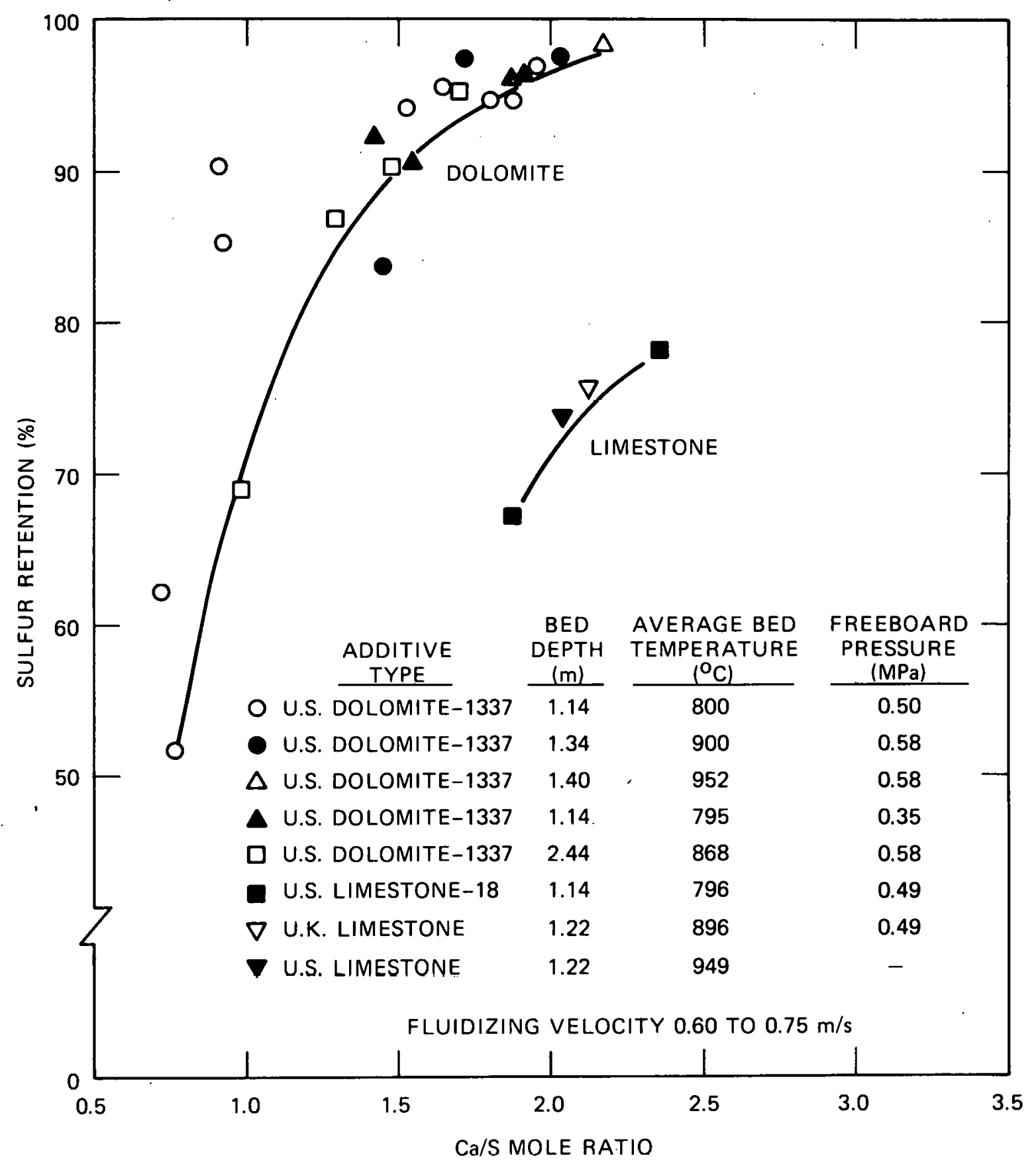

Fig. 1. Retention of sulfur in the BCURA $0.6 \times 0.9-m$ pressurized flusdized bed combustor. 


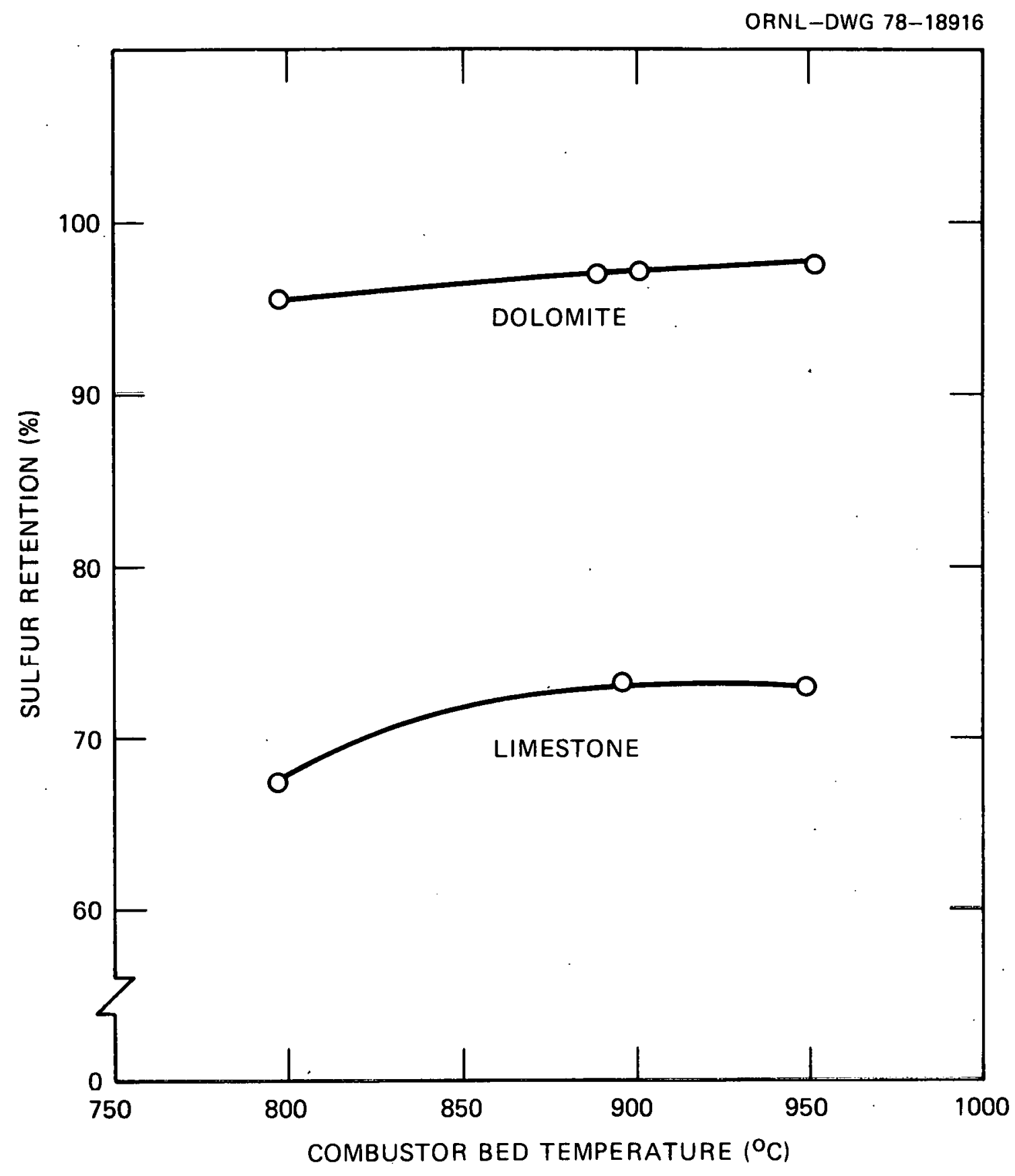

Fig. 2. Effect of combustor temperature on sulfur retention with $\mathrm{Ca} / \mathrm{S}$ mole ratio $=2$. Fluldizing velocity 0.6 to $0.75 \mathrm{~m} / \mathrm{s}$, bed depth 1.14 to $2.44 \mathrm{~m}$ and freeboard pressure 0.35 to $0.60 \mathrm{MPa}$. 


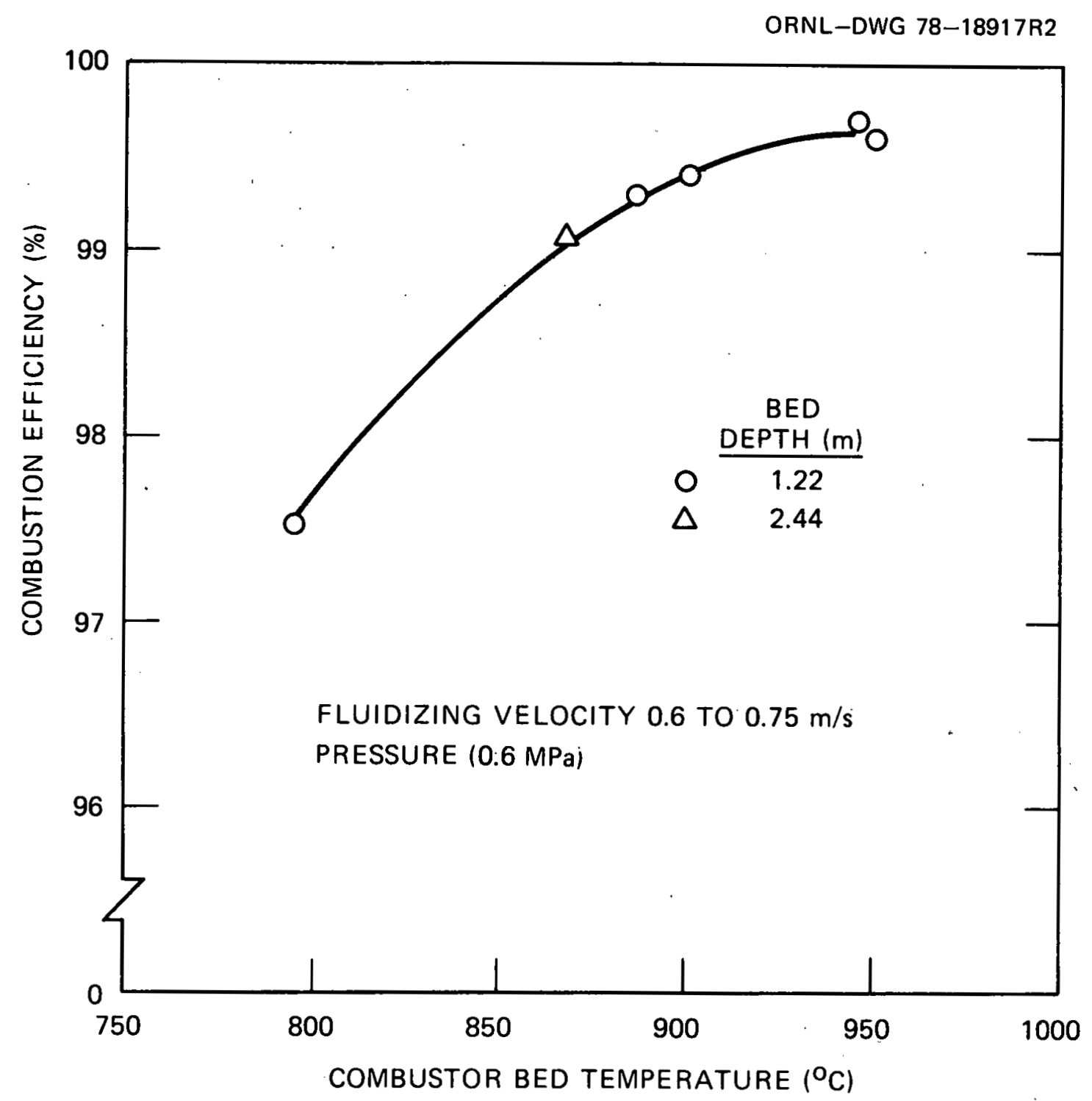

Fig. 3. Effects of combustor temperature on combustion efficiency with $17 \%$ excess combustion air. 
indicate a combustion efficiency of $98 \%$ which can be compared to $99.3 \%$ shown in Figure 3.

As of August 1978, the BCURA factlity is being used in connection with the Stal-Laval-American Electric Power program to develop a PFBC system. Turbine blade cascade tests are being run with $100 \%$ excess air and a combustion gas inlet temperature of $788^{\circ} \mathrm{C}\left(1450^{\circ} \mathrm{F}\right)$ into the cascade and gas velocities $527 \mathrm{~m} / \mathrm{s}$ (1730 ft/sec) leaving the simulated stator and $390 \mathrm{~m} / \mathrm{s}(1280 \mathrm{ft} / \mathrm{sec})$ leaving the simulated rotor. The first test of $200 \mathrm{hr}$ was terminated because of plugging of the drain from a cyclone separator. A $1000-\mathrm{hr}$ test is to be run next.

\section{Argonne National Laboratory}

The Argonne National Laboratory (ANL) has been conducting a basic research and development program since early 1969 to demonstrate the feasibility of the combustion of coal in a pressurized fluidized bed combustor. A 15-cm (6.0-in.) diam, pressurized, fluidized bed combustor capable of operating to $0.10 \mathrm{MPa}$ (10 atm) pressure and temperatures in the range of 775 to $975^{\circ} \mathrm{C}\left(1427\right.$ to $\left.1787^{\circ} \mathrm{F}\right)$ was used to investigate sulfur retention, combustion efficiency, additive utilization, and heat transfer coefficients.

A series of eleven experiments were performed in 1974 to demonstrate the effects of the bed temperature, fluidizing velocity, and the $\mathrm{Ca} / \mathrm{s}$ mole ratio upon the sulfur retention, nitrogen oxide levels in the flue gas, and the combustion efficiency. The operating conditions for these experiments are given in Table 3 , and some results are given in Table 4. These data indicate the $\mathrm{Ca} / \mathrm{S}$ mole ratio is the most significant source of variation in the sulfur retention. For $\mathrm{Ca} / \mathrm{S}$ ratios above 2.0 , the sulfur retention is generally above $90 \%$, which agrees well with the findings of BCURA as shown in Figures $\perp$ and 2 .

Since 1974, the 15-cm (6-in.) diam combustor has been operated in conjunction with a lime regeneration system.

\section{Combustion Power Company}

The Combustion Power Company began work on coupling a gas turbine to a fluidized bed burning solid waste in 1969 and subsequently shifted 
Table 3. Design operating conditions and matrix representation for the eleven experiments in the Latin-square

experimenta1 designs (Ref. 4)

\begin{tabular}{|c|c|}
\hline Equipment: & $\begin{array}{l}\text { 15-cm (6-in.) diam pressurized fluidized bed com- } \\
\text { bustor }\end{array}$ \\
\hline Coal: & Arkwright (Consolidation Coal Company) \\
\hline Additive: & Tymochtee dolomite (C. E. Duff and Sons) \\
\hline Pressure: & $0.8 \mathrm{MPa}$ (8 atm abs) \\
\hline Fluidized be & $0.91 \mathrm{~m}(3 \mathrm{ft})$ \\
\hline Excess air: & $\sim 15 \%\left(3 \% 0_{2}\right.$ in the dry flue gas $)$ \\
\hline
\end{tabular}

Levels of independent variables

Leve1 $1 \quad$ Level 2 Level 3

$\begin{array}{lccc}\text { (T) Temperature, }{ }^{\circ} \mathrm{C}\left({ }^{\circ} \mathrm{F}\right) & 788(1450) & 843(1550) & 899(1650) \\ \text { (R) Ca/S mole ratio } & 1.0 & 2.0 & 3.0 \\ \text { (V) Gas velocity, m/s (ft/sec) } & 0.61(2.0) & 1.07(3.5) & 1.52(5.0)\end{array}$

in 1974 to operation with coa1.5-8 By 1976, the unit operated at $0.4 \mathrm{MPa}$ (4 atm) pressure had accumulated approximately $600 \mathrm{hr}$ of turbine operation at an inlet temperature of $760^{\circ} \mathrm{F}\left(1400^{\circ} \mathrm{F}\right)$. The hot gas cleanup system for these tests was operated at temperatures of 815 to $860^{\circ} \mathrm{C}$ $\left(1500\right.$ to $1580^{\circ} \mathrm{F}$ ) with cooling downstream of the last stage of particle separation so as to not exceed the design turbine inlet temperature of $788^{\circ} \mathrm{C}\left(1450^{\circ} \mathrm{F}\right)$. The hot gas cleanup devices used in this series of tests consisted of tangential entry cyclones and 15.2- and 1.6-cm (6- . and 0.6-in.) multicyclones. In each test, the multicyclones became ineffective after a few hours of operation owing to ash plugging which resulted in heavy fouling and erosion in the turbine. Subsequent work has been directed toward the development of granular bed filters. ${ }^{8}$

\section{NASA-Lewis}

The NASA-Lewis pressurized fluidized bed test system is primarily for determining the effects of exhaust gases from the combustion of 
Table 4. Operating conditions and flue-gas analyses for the eleven experiments investigating the effects of independent operating variables (Ref. 4)

Coal: Arkwright (2.82\% sulfur)

Adcitive: Tymochtee Dolomite

Flididized bed height: $0.91 \mathrm{~m}(3 \mathrm{ft}$ )

System pressure: $0.8 \mathrm{MPa}$ ( 8 atm abs)

\begin{tabular}{|c|c|c|c|c|c|c|c|c|}
\hline \multirow{2}{*}{ Experiment } & \multirow{2}{*}{$\begin{array}{l}\text { Combustion } \\
\text { temperature } \\
{ }^{\circ} \mathrm{C}\left({ }^{\circ} \mathrm{F}\right)\end{array}$} & \multirow{2}{*}{$\begin{array}{c}\mathrm{Ca} / \mathrm{S} \text { mole } \\
\text { ratio }\end{array}$} & \multirow{2}{*}{$\begin{array}{c}\text { Gas } \\
\text { velocity, } \\
\mathrm{m} / \mathrm{s}(\mathrm{ft} / \mathrm{sec})\end{array}$} & \multicolumn{5}{|c|}{ Flue-gas analysis ${ }^{a}$} \\
\hline & & & & $0_{2}, \%$ & $\mathrm{CO}_{2}, \%$ & $\mathrm{SO}_{2}, \mathrm{ppm}$ & NO, ppm & $\mathrm{CO}, \mathrm{ppm}$ \\
\hline VAR-1 & $785(1445)$ & 2.9 & $0.64(2.1)$ & 2.7 & 17 & 120 & 190 & 100 \\
\hline VAR-2 & $852 （ 1565$ & 2.9 & $1.46(4.8)$ & 3.0 & 17 & 130 & 210 & 30 \\
\hline VAR-3 & $857(1575)$ & 1.1 & $0.64(2.1)$ & 3.0 & 15 & 350 & 140 & 30 \\
\hline VAR-4 & $899(1650)$ & 1.9 & $0.69(2.3)$ & 3.0 & 16 & 120 & 180 & 50 \\
\hline VAR-5 & $793(1460)$ & 1.0 & $1.02(3.4)$ & 3.0 & 15 & 680 & 150 & 760 \\
\hline VAR- 6 & $852(1565)$ & 2.0 & $1.10(3.6)$ & 3.0 & 16 & 170 & 190 & 30 \\
\hline VAR-6-R & $849(1560)$ & 2.1 & $1.10(3.6)$ & 2.9 & 15 & 210 & 180 & 30 \\
\hline VAR-6-2R & $843(1550)$ & 2.0 & $1.07(3.5)$ & 3.0 & 16 & 190 & 160 & 30 \\
\hline VAR-7 & $793(1460)$ & 2.2 & $1.28(4.2)$ & 2.7 & 16 & 260 & 150 & 90 \\
\hline VAR-8 & $88 B(1630)$ & 3.2 & $1.10(3.6)$ & 3.0 & 17 & 130 & 270 & 40 \\
\hline VAR-9 & $907(1665)$ & 1.0 & $1.49(4.9)$ & 2.9 & 16 & 850 & 120 & 40 \\
\hline
\end{tabular}

$a_{\text {Dry basis. }}$ 
coal upon turbine blade material. The fluidized bed is a combination of a cylindrical and a conical bed. 9 The cylindrical bed is $22.6 \mathrm{~cm}$ (8.90 in.) in diameter. The conical bed expands to a diameter of 50.6 $\mathrm{cm}$ (20 in.) The system is designed to operate over a pressure range of 0.17 to $1.36 \mathrm{MPa}$ ( 1.7 to $13.6 \mathrm{~atm}$ ) and a temperature range of 760 to $1090^{\circ} \mathrm{C}\left(1400\right.$ to $\left.1994^{\circ} \mathrm{F}\right)$.

The fuel is burned in the lower cylindrical section, while the upper conical bed serves as a fixed bed filter for the hot flue gases supplied to a turbine test section. The system became operable in 1977. The first test program was to involve the use of a turbine section, high-temperature cyclones, and a high-temperature ceramic filter.

\section{Westinghouse Research and Development Center}

A high-temperature, high-pressure test facility is being constructed by the Westinghouse R\&D Center to test particulate control equipment. The facility is designed to investigate the effects of temperature, pressure, flow rate, particle type, loading, and size distribution on the performance of various types of particulate removal devices. ${ }^{10}$ Shakedown runs were expected to begin in 1978. The test unit is designed for a gas flow rate of $0.24 \mathrm{~m}^{3} / \mathrm{s}\left(8.5 \mathrm{ft}^{3} / \mathrm{sec}\right)$ at $1.0 \mathrm{MPa}(10 \mathrm{~atm})$ and $875^{\circ} \mathrm{C}$ $\left(1607^{\circ} \mathrm{F}\right)$.

\section{Curtiss-Wright Corporation}

The Curtiss-Wright program to develop a pressurized fluidized bed combustion system coupled to a gas turbine has entailed, as a first major step, the design and construction of a facility called the Small Gas Turbine-Pressurized Fluidized Bed (SGT/PFB) rig. 11 This unit employs an $0.8-\mathrm{m}(2.5-\mathrm{ft})$ diam fluidized bed furnace designed to operate at $0.65 \mathrm{MPa}$ $(6.5 \mathrm{~atm})$. A portion of the combustion products passes through a series of cyclone separators and a granular bed filter en route to a small gas turbine. The effectiveness of various designs for the particle removal equipment will be determined as a function of the principal variables. Concurrently, the effects of the particulate content of the combustion gas entering the gas turbine on turbine bucket erosion and deposits will 
be investigated. The test $\mathrm{rig}$ has been undergoing shakedown tests as of January 1978.

\section{Grimethorpe Experimental Facility}

A pressurized fluidized bed combustor experimental facility under construction at Grimethorpe, England (jointly financed by the U.K., U.S.A., and West Germany, in equal shares), is designed to investigate combustion efficiency, heat transfer, gas cleanup, corrosion, and energy recóvery. 12

The basic design characteristics of the facility are:

$\begin{array}{ll}\text { Bed temperature } & 850^{\circ} \mathrm{C}\left(1560^{\circ} \mathrm{F}\right) \\ \text { Superficial velocity } & 2.5 \mathrm{~m} / \mathrm{s}(8.2 \mathrm{ft} / \mathrm{sec}) \\ \begin{array}{l}\text { Operating pressure } \\ \text { Internal cross section }\end{array} & 1.0 \mathrm{MPa}(10 \mathrm{~m} \times 2 \mathrm{~m}(6.6 \mathrm{ft} \times 6.6 \mathrm{ft}) \\ \begin{array}{l}\text { Bed depth (approxi- } \\ \text { mately) }\end{array} & 4 \mathrm{~m}(13 \mathrm{ft}) \\ \begin{array}{c}\text { Hot gas flow (approxi- } \\ \text { mately) }\end{array} & 36 \mathrm{~kg} / \mathrm{s}(79 \mathrm{lb} / \mathrm{sec})\end{array}$

The initial system will be supercharged by a steam turbine-driven centrifugal compressor to obviate potential problems that may arise from a flue gas turbine drive. The initial cascade tests, scheduled for the 1979-1980 period, will include two cascades in series to simulate the erosion of the blade pressure surface near the trailing edge. Provisions may be incorporated in the facillty to allow the testing of a flue gas turbine with a much lower inlet gas temperature than the combustion gas temperature leaving the bed.

Tentatively, a major objective of the flue gas turbine experimental program is to determine the feasibility of running a bed supercharged by a turbine-compressor unit that does not produce electricity. Tests will also be made to investigate the feasibility of operation at higher temperatures that would make it possible to get a substantial electrical output from the gas turbine. 13 
SURVEY OF TURBINE EROSION, CORROSION, AND DEPOSIT PROBLEMS

The most important feasibility question associated with pressurized fluidized bed coal combustion systems is the feasibility of employing a gas turbine-compressor to provide the high pressure air to the fluidized bed. Unless this can be done with a gas turbine, the power requirements for the air compressors are exorbitant. This section reviews the extensive test and operating experience with turbines in which the gas entering the turbine contained particulate matter. The experience with particulate removal equipment is also reviewed to give an indication of the levels of particle concentration that can be obtained with the equipment that has been tested to date. (A study ${ }^{14}$ of this problem was completed recently at ORNL as a part of an overall survey of advanced energy systems.)

\section{Experience with Erosion in Wet Steam Turbines}

One's first thought is to consider the experience that has been gained with turbine bucket erosion in steam power plants. It has been found that the erosion phenomena with wet steam are substantially different from those found in gas turbines handling solid particulates; as one might expect, the solid particles give a much more severe erosion problem. Further, the solid particles also give difficulty with deposits.

\section{Locomotive Development Committee (LDC) Experience}

By 1945, the successful operation of a gas turbine for supercharging Velox boilers, diesel engines, and aircraft engines together with Swiss experience with commercial gas turbines led to the launching of a project to develop a coal-burning gas turbine for locomotive service. This project was launched with great enthusiasm and staffed with some outstanding engineers. Twelve years later the effort was terminated because in spite of some fine englneering work and some very clever innovations it was not possible to obtain an operational power plant. The program began with some highly encouraging initial runs in which the turbine inlet temperature was kept to less than $538^{\circ} \mathrm{C}\left(1000^{\circ} \mathrm{F}\right)$; little difficulty with corrosion or deposits was experienced. However, at these 
lower temperatures it was not possible to produce a significant useful output, and, when higher temperatures [the goal was $676^{\circ} \mathrm{C}\left(1250^{\circ} \mathrm{F}\right)$ ] were employed, severe erosion and fouling of the turbine were experienced. A.wide variety of particulate removal equipment was designed, built, and tested, but none proved sufficiently effective to permit a long operating 1ife. The longest period of operation obtained was about $1400 \mathrm{hr}$, involving turbine inlet temperatures of 593 to $676^{\circ} \mathrm{C}\left(1100\right.$ to $\left.1250^{\circ} \mathrm{F}\right)$. The run was terminated due to a loss of power from the turbine.

After the program was dropped, both the Bureau of Mines and the Union Pacific Railroad proceeded with efforts to solve the erosion and deposit problems, but 1ittle further improvement was effected in spite of the fact that a redesigned turbine was built to take advantage of the experience gained in the LDC program.

\section{Australian Program}

In the 1950's, the Australian government initiated a program to try to develop a gas turbine that would operate on Australian coal. The program took advantage of the experience gained in the LDC, Bureau of Mines, and Union Pacific programs and succeeded in getting what appeared to be lower erosion and deposit rates. However, the longest successful run of a turbine was $125 \mathrm{hr}$. On the basis of the relatively low erosion and deposit rates experienced in this run, the Australian final report concluded that a $50,000-\mathrm{hr}$ life could be obtained. In view of the nonlinear characteristics of deposition in particular, it is an open question whether this large extrapolation was valid. In any event, the program was discontinued.

\section{Satalytic Cracking Unit Experience}

There has been extensive experience with yas turbines used to pruvide air at pressures of 0.3 to. $0.5 \mathrm{MPa}$ ( 3 to $5 \mathrm{~atm}$ ) for regenerating the catalyst in catalytic cracking units. Up until the 1950s, the turbine inlet temperature for these un1ts liad been limited to lese than $538^{\circ} \mathrm{C}\left(1000^{\circ} \mathrm{F}\right)$ hecause of erosion problems. Efforts were made to capitalize on the LDC experience with improved particulate removal equipment, notably the 
multiclone particle separator, which is a large number of small cyclones operated in parallel. The small cyclones are more effective in removing small particles than large cyclones because of the fact that the radial acceleration is larger for the small radii of the multiclones. Extensive development work made it possible to obtain particle concentrations (following two stages of conventional cyclones and a third stage of a multiclone unit) of around $100 \mathrm{ppm}$ with the bulk of the material being in the particle size range below 1 micron. This particle removal equipment, in turn, made it possible to operate the turbine with inlet temperatures as high as $621^{\circ} \mathrm{C}\left(1150^{\circ} \mathrm{F}\right)$, which is sufficient to produce substantial amounts of useful electrical power. Several important additional developments were required to make this possible. These included the use of tungsten carbide-coated stellite blades in the turbine, the use of a single-stage turbine with a very clean inflow condition so that the particles would not be segregated in any limited portion of the flowstream, and the use of blades substantially thicker than would be favored if the prime objective was a high aerodynamic efficiency in the turbine. With these developments, a turbine life of the order of 15,000 hr has proved possible with turbine inlet temperatures as high as $621^{\circ} \mathrm{C}\left(1150^{\circ} \mathrm{F}\right)$. Note that the experience in this development program showed clearly that the erosion rate is a quite steep function of the operating temperature.

\section{Blast Furnace Gas Turbines}

The energy available from the carbon monoxide present in blast furnace gas has been utilized in gas turbines for the past 40 years. However, the particulate matter in the blast furnace gas has made it necessary to employ a particulate removal system to keep turbine bucket erosion and deposits to a tolerable level. Extensive tests, both in Europe and the U.S., have led to the use of cyclone separators followed by coolers and two stages of water scrubbers in order to get the particulate content to an acceptable level. This work has shown that particulate contents in the turbine working fluid must be kept to about $1 \mathrm{ppm}$ for turbine inlet temperatures of $730^{\circ} \mathrm{C}\left(1346^{\circ} \mathrm{F}\right)$ : 


\section{Air Filter Requirements for Commercial Gas Turbines}

Specifications on the particulate content in the airstream entering commercial gas turbines call for particulate contents of no more than $1 \mathrm{ppm}$. This ordinarily entails the use of filters which are placed in the inlet airstream ahead of the compressor.

Permissible Ash Content of Fuel 0ils for Gas Turbines

Difficulties with deposits in gas turbines have been experienced with conventional No. 2 fuel oil. As a consequence, the fuel oil for use in gas turbines is required to have an ash content less than 1 part in 10,000. This is equivalent to a particulate content in the hot gas stream of $\sim 1$ ppm.

\section{Gas Turbines Used with Coal Gasification Plants}

The Lünen Plant of Steinkohlen Elektrizität AG in Germany is a combined cycle, gas turbine-steam plant coupled to a low Btu coal gasification plant employing Lurgi gasifiers. This plant included cyclone separators for removing particulates in the gas stream coming from the Lurgis together with provisions for cooling and cleaning the gas in two stages of water scrubbers.

\section{Deposits in High Temperature Gas Turbines}

Difficulties with turbine deposits apparently become much more serious as the turbine inlet temperature is increased above $1093^{\circ} \mathrm{C}$ $\left(2000^{\circ} \mathrm{F}\right)$. One of the first indications of this was experienced at the Philadelphia Navy Yard in 1973 when serious deposits were noted after $150 \mathrm{hr}$ of testing in which about half was at turbine inlet temperatures of $1204^{\circ} \mathrm{C}\left(2200^{\circ} \mathrm{F}\right)$. The deposits were formed of $\mathrm{Fe}_{2} \mathrm{U}_{3}$ that apparently entered in the inlet air which had a total particulate content of only $0.06 \mathrm{ppm}$. Subsequent investigations disclosed that this particulate content is common in the cleanest air to be expected in an industrial environment, and similar difficulty with deposits of this sort has been experienced at General Electric, United Technologies, and NASA-Lewis Laboratory. Deposits formed appear to be a very adherent coating of 
iron-oxide which appears on both the pressure and suction surfaces of the blade and cannot be cleaned off by motoring the turbine while injecting crushed nutshells and hot water. Note that the sintering point of iron-oxide is approximately $1121^{\circ} \mathrm{C}\left(2050^{\circ} \mathrm{F}\right)$, and there are probably somewhat lower melting point materials present which aid in the sintering process.

\section{Summary}

A review of the experience gained in the past 40 years with removal of particulates from hot gases supplied to gas turbines indicates that by special handling of the gas, it is possible to operate gas turbines with inlet temperatures up to about $621^{\circ} \mathrm{C}\left(1150^{\circ} \mathrm{F}\right)$ with particulate contents of the order of $100 \mathrm{ppm}$ with tolerable rates of turbine bucket erosion. However, where material having a low sintering temperature is present, as is the case with coal ash, the maximum permissible turbine inlet temperature from the standpoint of deposits appears to be of the order of $538^{\circ} \mathrm{C}\left(1000^{\circ} \mathrm{F}\right)$ if the particulate content of the hot gas is of the order of $100 \mathrm{ppm}$. For operation in the $816^{\circ} \mathrm{C}\left(1500^{\circ} \mathrm{F}\right)$ to $871^{\circ} \mathrm{C}$ $\left(1600^{\circ} \mathrm{F}\right)$ range, it appears from extensive experience with commercial gas turbines that the particulate content must be kept below 1 ppm to avoid difficulties with either erosion or deposits. If the gas temperature is increased to over $1093^{\circ} \mathrm{C}\left(2000^{\circ} \mathrm{F}\right)$, it appears that the particulate content must be kept to a still lower level. Figure 4 summarizes this experience in graphical form.

The weight of the evidence cited above may lead to a change in objectives in the joint U.K./U.S./West Germany program for the PFB facility at Grimethorpe, England; consideration is now being given to placing early emphasis on determining the feasibility of supercharging a fluidized bed with a. gas turbine using an inlet temperature of no more than $538^{\circ} \mathrm{C}\left(1000^{\circ} \mathrm{F}\right)$. An effort to achieve higher turbine inlet temperatures would follow in a second phase of the program if this approach is adopted. 
ORNL-DWG 79-4703 ETD

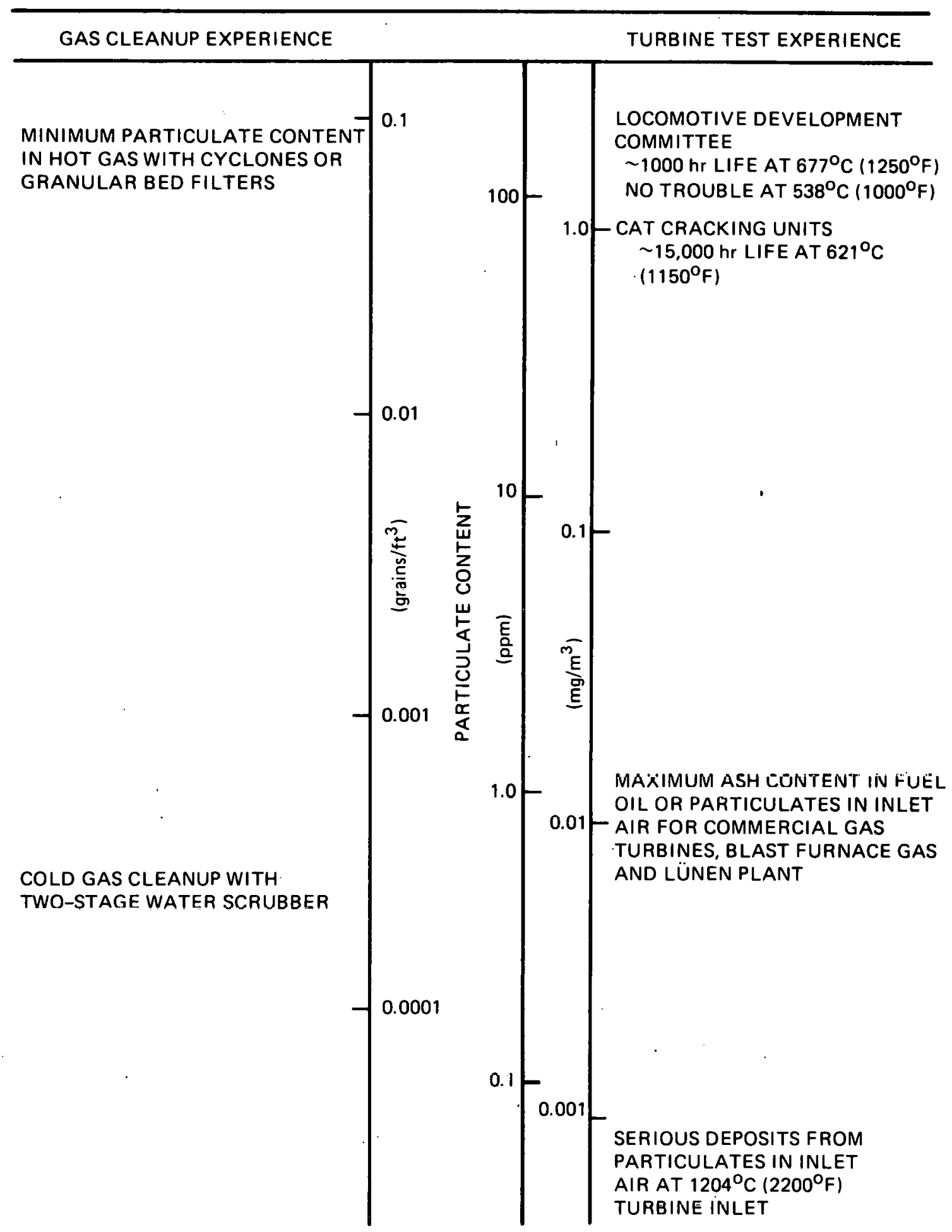

Fig. 4. Summary of experience with particulate removal equipment and gas turbines operating with particulates in the gas. 


\section{SURVEY OF HOT GAS FILTER TESTS}

The Locomotive Development Committee work was concerned primarily with the development of cyclone filters including the multiclone units mentioned above. A little work was done on electrostat1c precipitators but it was found that deposits of ash on the insulators had sufficient conductivity at high temperature to cause high-tension shorts, hence the electrostatic precipitators were not effective in the temperature region of interest.

The catalytic cracking unit gas turbine experience paralleled that of the LDC but was extended to obtain a long life in the multiclone filters through the use of ceramic inserts to resist the erosive effects of the particulate matter being separated in the tiny cyclone elements.

Combustion Power, Inc., in Menlo Park, initially under an EPA contract and subsequently under DOE contracts, is attempting to run a fluidized bed coal combustion system using granular bed filters between the fluidized bed coal combustion system and the turbine. This work has been under way for about four years; a successful filter has not yet been demonstrated.

Work at BCURA in England on fluidized beds had included some tests of blade cascades with two or three stages of cyclones between the fluidized bed and the blade cascades. The two initial tests appeared to be favorable but the most recent test did not turn out well, apparently because of a malfunction in the lower stage cyclone separator. However, it should be noted that the velocity of the gas approaching the cascade was relatively low in the early tests so that erosion should not have been expected. Further, the tests were only of the order of $500 \mathrm{hr}$ so that they were not definitive from the standpoint of the accumulation of deposits.

Work at Exxon Research Laboratory under EPA contract has entailed the operation of a pressurized fluidized bed in conjunction with a variety of cyclone and granular bed filters. After two years of test work, the best gas cleanup that has been accomplished has been to achieve particulate contents of the order of $1 \mathrm{ppm}$, but this level of gas cleanup can be sustained only by frequent backflows of gas to clear the bed, and 
even then cannot be sustained for more than a day before excessive pressure drops are experfenced.

Work on electrostatic precipitators for use with fluidized bed combustion systems has been initiated in Germany, but no experimental data have been obtained up to the time of writing. A survey of hot gas filtering equipment capabilities has been completed recently at ORNL.15

\section{SURVEY OF DESIGN STUDIES FOR FULL-SCALE PFBC's}

This section includes a review of the recent design studies on PFBC systems that were carried out by the following organizations.

1. Westinghouse, Energy Conversion Alternatives Study (ECAS) 16

2. General Electric (GE), Energy Conversion Alternatives Study (ECAS) 17,18

3. Burns \& Roe et al.19

4. Curtiss-Wright 20

5. ORNL ${ }^{21}$

In the first two designs, the PFBC serves as a steam generator, whereas in the next two, the PFBC is actually a gas generator and gas heater coupled to a gas turbine with heat recovered from the turbine exhaust for a steam bottoming cycle. The fifth system is similar to the first two except that the hot gases leaving the fluidized bed are cooled to $\sim 38^{\circ} \mathrm{C}\left(1000^{\circ} \mathrm{F}\right)$ before entering the gas turbine so that its output is only sufficient to drive the compressor. A short, general description of each system is presented below followed by a more detailed discussion of the major design parameters and assumptions as incorporated by the respective designers. These assumptions may be compared to the state of the art of development presented elsewhere in this report. Also, where possible, contrasts between these designs and recent AFBC system designs are noted.

\section{General Description of Power Plants}

Each designer's system is described briefly with a simplified schematic diagram included. Major system parameters are tabulated in Table 5, following, for comparison. 
Table 5. Comparison of recent PFBC conceptual designs

\begin{tabular}{|c|c|c|c|c|}
\hline . & $\begin{array}{c}\text { GE-ECAS } \\
1976\end{array}$ & $\begin{array}{l}\text { Westinghouse-ECAS } \\
1976\end{array}$ & $\begin{array}{c}\text { Burns \& Roe } \\
1977\end{array}$ & $\begin{array}{c}\text { Curtiss-Wright } \\
1977\end{array}$ \\
\hline $\begin{array}{l}\text { Overall plant efficiency } \\
\% \text { fuel HHV }\end{array}$ & 39.2 & 39.0 & 38.0 & 38.8 \\
\hline $\begin{array}{l}\text { Fluidized bed temperature } \\
{ }^{\circ} \mathrm{C}\left({ }^{\circ} \mathrm{F}\right)\end{array}$ & $899(1650)$ & $1010 \cdot(1850)$ & $899(1650)$ & $899(1650)$ \\
\hline $\begin{array}{l}\text { Gas turbine inlet temperature } \\
{ }^{\circ} \mathrm{C}\left({ }^{\circ} \mathrm{F}\right)\end{array}$ & $871(1600)$ & $960(1760)$ & $871(1600)$ & $871(1600)^{\prime}$ \\
\hline $\begin{array}{l}\text { Steam conditions } \\
\left.\mathrm{MPa},{ }^{\circ} \mathrm{C} \text { (psia, }{ }^{\circ} \mathrm{F}\right)\end{array}$ & $\begin{array}{ll}24.4, & 538 \\
(3513, & 1000)\end{array}$ & $\begin{array}{ll}24.2, & 538 \\
(3515, & 1000)\end{array}$ & $\begin{array}{ll}16.6, & 538 \\
(2400, & 1000)\end{array}$ & $\begin{array}{ll}5.5, & 441 \\
(800, & 825)\end{array}$ \\
\hline $\begin{array}{l}\text { Fluidized bec pressure } \\
\mathrm{MPa} \text { (atm) }\end{array}$ & $1.0(10)$ & $1.0(10)$ & $1.0(10)$ & $0.71(7)$ \\
\hline Got gas cleanup & cyclone/GBF ${ }^{a}$ & cyclone/GBF & cyclone/GBF & cyclone/cyclone \\
\hline Salcium/sulfur mole ratio & 2.0 & 1.5 & 1.0 & $\therefore-$ \\
\hline $\begin{array}{l}\text { Fuel feeding } \\
\mathrm{m}^{2}\left(\mathrm{ft}^{2}\right) \text { per injector }\end{array}$ & $0.56(6.0)$ & $2.14(23.0)$ & - & - \\
\hline
\end{tabular}

$a_{\text {Granular bed filter. }}$ 


\section{General Electric system}

The steam cycle selected by GE for the ECAS study was a conventional supercritical cycle with one reheat.17,18 Two low pressure feedwater heaters were utilized plus one more which served as an economizer by cooling the exhaust gases from the gas turbine. The thermodynamic cycle efficiency was $41.3 \%$ and the net power output of the system is listed as 904 MW(e) with about 23\% of the output attributable to the gas turbines. The condenser pressure was set at $0.0078 \mathrm{MPa}(2.3 \mathrm{in} . \mathrm{Hg})$ absolute. A simplified schematic of the GE configuration is depicted in Figure 5 .

\section{Westinghouse system}

The Westinghouse design also incorporated a supercritical steam cycle with one reheat. ${ }^{16}$ Seven stages of feed heating were used in addition to the turbine exhaust cooler/economizer. The gas turbine in this study was described as utilizing air cooling on the first two blade rows. The thermodynamic cycle efficiency was reported as being $42.3 \%$ and the net power of the system as $679 \mathrm{MW}(\mathrm{e})$ with the gas turbines contributing about $20 \%$. A condenser pressure of $0.0085 \mathrm{MPa}(2.5 \mathrm{in}$. $\mathrm{Hg}$ ) was selected. A simplified diagram of the Westinghouse conceptual power plant is presented in Figure 6.

Burns \& Roe, United Technologies, and Babcock \& Wilcox

The system conceived by these organizations comprised a PFBC for firing a topping gas turbine and a supplementally-fired AFBC steam generator for a steam bottoming cycle.19 The gas turbine exhaust, which is composed of the PFBC combustion products and a large quantity of air heated in the PFBC, is used as combustion air in the AFBC steam generator. The net output for this conceptual design was $574 \mathrm{MW}(\mathrm{e})$, about $21 \%$ of which was generated by the gas turbine.

The most prominent feature in this PFBC design is the use of the furnace as an air heater rather than as a steam generator. By mixing this clean heated air with the combustion gases, the working fluid for the gas turbine presents a hot gas cleanup problem less difficult 
ORNL-DWG 78-18918

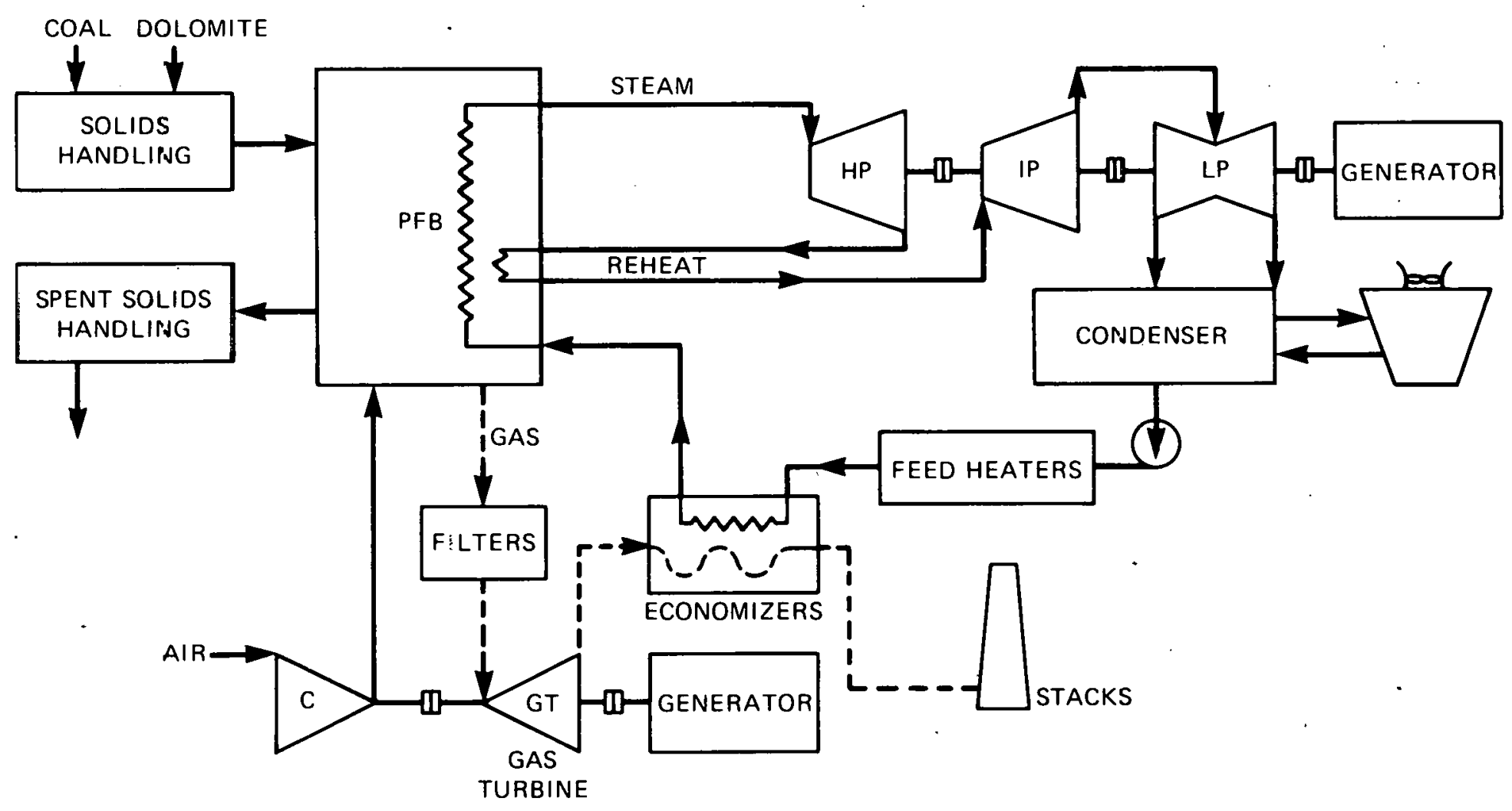

Fig, 5. Simplified schematic diagram for General Electric PFBC steam power plant, Ref. 17, 18 . 


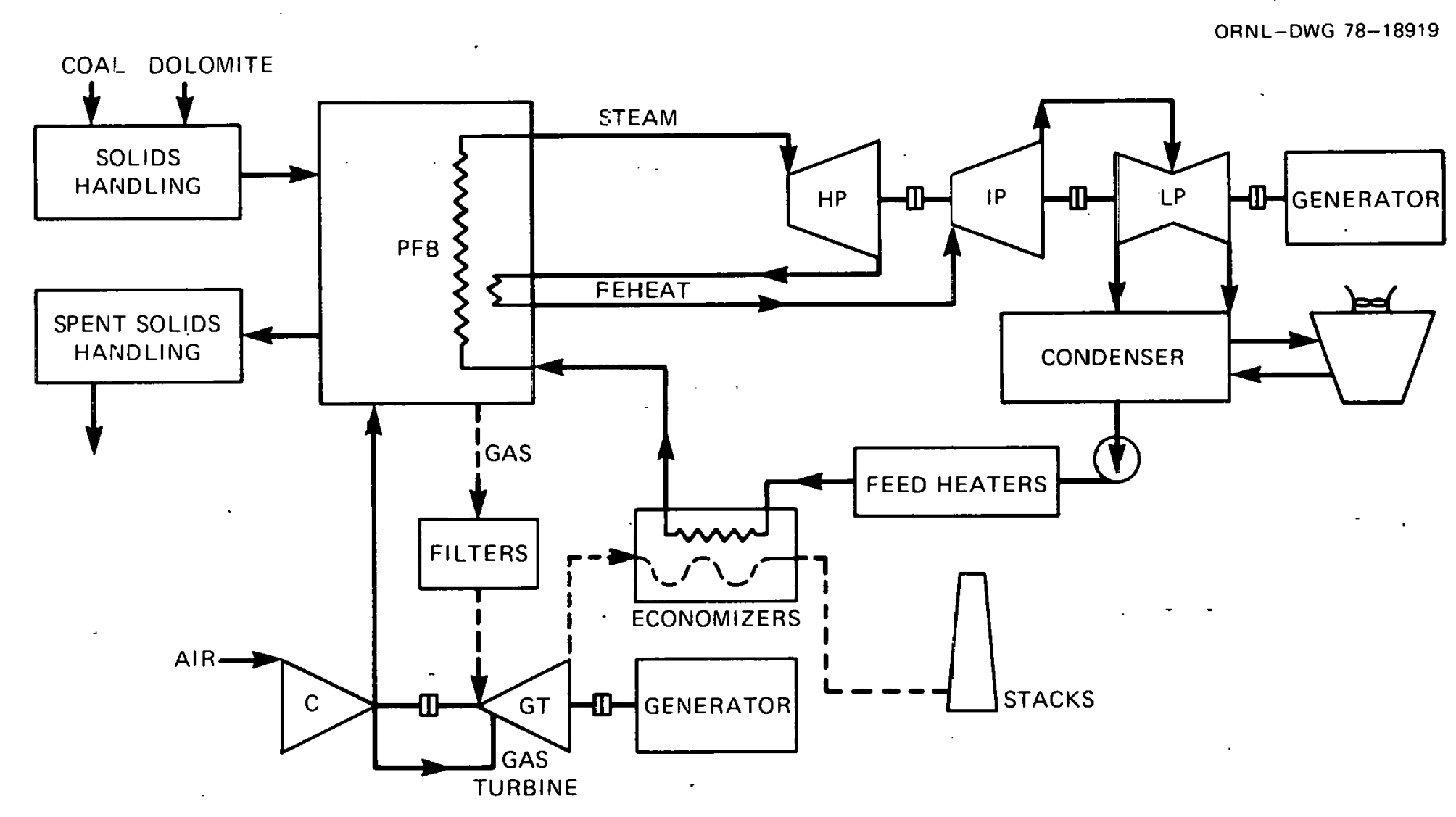

Fig. 6. Simplified schematic diagram for Westinghouse PFBC steam power plant, Ref. 16. 
than for the systems of Figures 5 and 6 . The power plant cycle is shown schematically in Figure 7.

\section{Curtiss-Wright}

The design under development by Curtiss-Wright 11,20 is similar to that of Burns \& Roe et al. Curtiss-Wright, however, has elected to use a more conventional unfired heat recovery steam generator and a lower pressure steam bottoming cycle. The gas turbine working fluid is, again, a mixture of clean, hot air and combustion gases. In this system, the gas turbine is responsible for about $66 \%$ of the plant power output. The turbine blades are to be protected from erosion and corrosion by transpiration air. Few design details were given in the reports on this system available to the writers. The proposed system is diagrammed in Fig. 8.

The significant design and performance parameters of the respective designs are compared in Table 5. These parameters are discussed individually in greater detail in the following subsections.

\section{Oak Ridge National Laboratory}

In an effort to exploit the advantages of a pressurized fluidized bed while avoiding the severe problems of erosion, corrosion, and deposits caused by coal combustion products in a high-temperature gas turbine, a design for a turbo-supercharged steam generator was evolved at ORNL. 21 This system is essentially an 0.3 to $0.5 \mathrm{MPa}$ ( 3 to $5 \mathrm{~atm}$ ) Velox boiler (of which over 100 oil-fired units have been built in Europe). Combustion gas cooled to 427 to $538^{\circ} \mathrm{C}\left(800\right.$ to $\left.1000^{\circ} \mathrm{F}\right)$ would serve to power a gas turbine giving sufficient output to drive the compressor. (No significant electrical output would be obtained from the gas turbine.) As indicated in the previous section, this should make it possible to get an acceptable turbine system life with good reliability.

In addition to reducing the furnace size and cost relative to an $A F B C$, the system is believed to have the further advantage of giving much improved control characteristics over either an AFBC or the other 


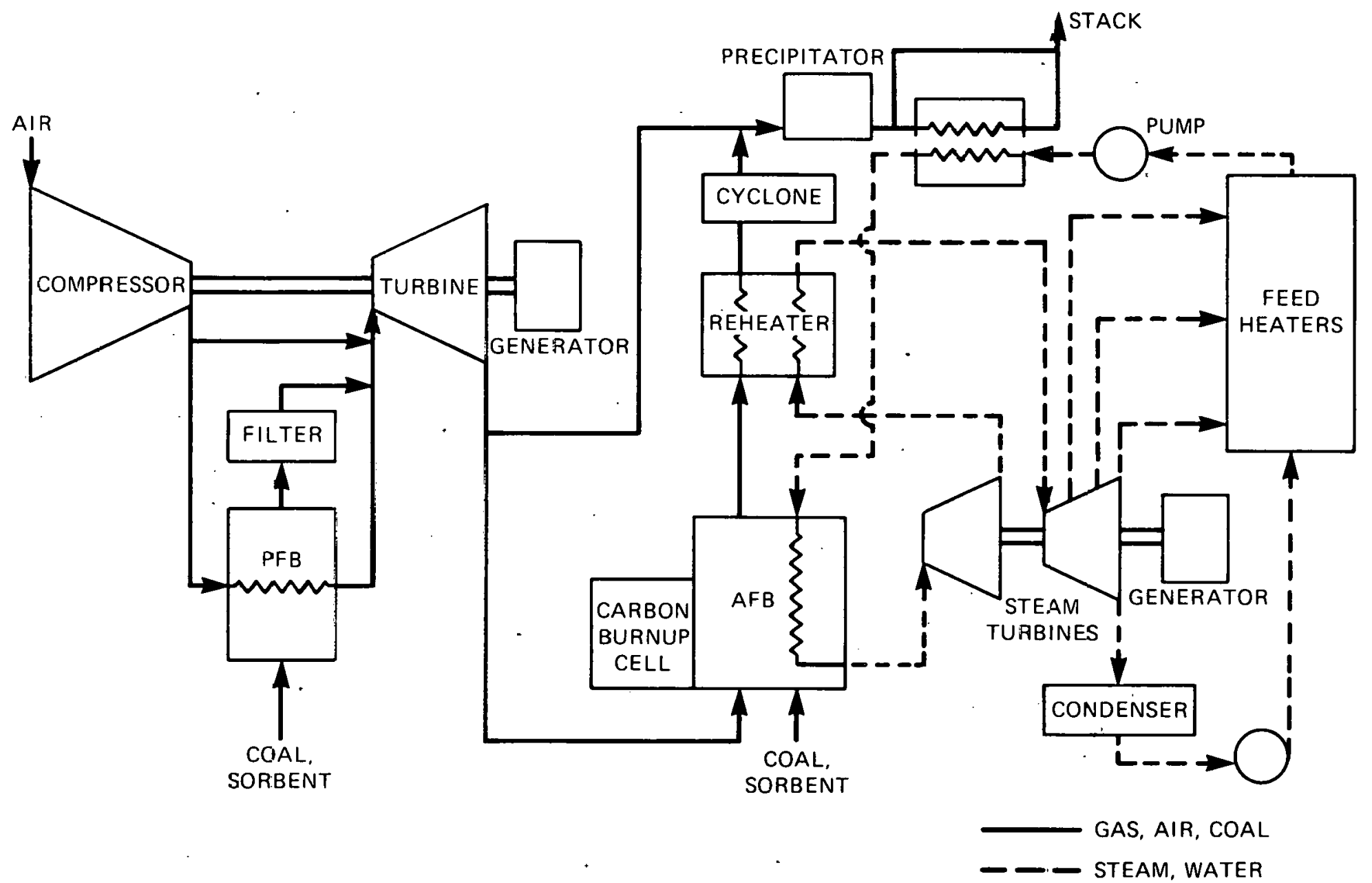

Fig. 7. Burns \& Roe PFB/AFB combined cycle power plant, Ref. 19. 


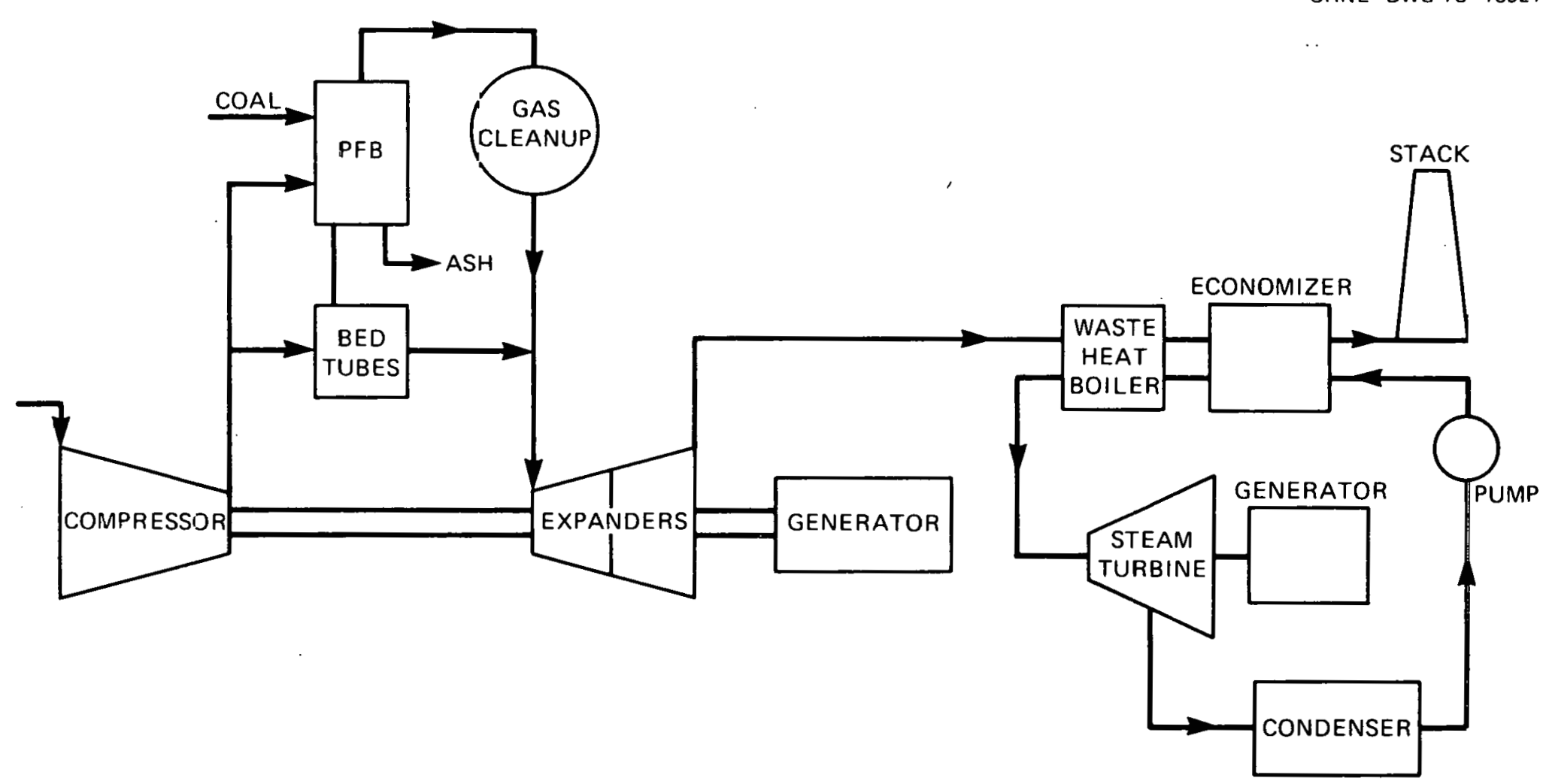

Fig. 8. Diagram of Curtiss-Wright PFBC power system, Ref. 11. 
PFBC's previously described. Good startup characteristics would be obtained by starting at atmospheric pressure with a bed only about $0.3-\mathrm{m}$ $(1-f t)$ deep with no steam generator tubes in the bed to impose a large heat load. The bed depth, combustion air velocity, and furnace pressure would then be increased linearly with power. Increasing both the superficial gas velocity through the bed and the furnace pressure by a factor of $\sim 3$ each should make possible a turn-down ratio of $\sim 10$. Note that by using a free turbine rather than one coupled to a generator, the turbine speed and compressor discharge pressure can be varied to give a relatively simple control system.

\section{Comparison of Selected Design and Performance Parameters}

Furnace size, weight, and materials

Representative furnace data from several design studies indicate an advantage in both size and weight for PFBC systems over AFBC systems (see Table 6). The extent of this advantage is a strong function of the detail designs. For example, Babcock \& wilcox selected a relatively low air velocity through the bed, resulting in a perhaps larger than typical plan area requirement.

None of the steam cycle design studies indicated that any materials more exotic than stainless steel would be required for the boiler tubes. However, the PFBC air heaters may require a more expensive tube material than austenitic stainless steel because the tube temperature will run closer to that of the fluidized bed than is the case for a steam generator. 19

The deep PFBC beds permit the use of vertical boiler tubes and natural circulation boiling which is thought to be a simplifying design configuration. Both ElAS dejsigns, however, ullilzed livizintal serpen tine tubes in the bed. The Burns \& Roe and Curtiss-Wright air heater designs specify the vertical arrangement.

\section{Sorbent requirements}

Conceptual designs for PFBC systems have taken advantage of the favorable sulfur retention potential of the PFBC by incorporating higher 
Table 6, Comparison of $\mathrm{PFBC}$, AFBC furnace configurations

\begin{tabular}{|c|c|c|c|}
\hline & Genera1 $\underset{(\text { ECAS })}{\text { Electric PFBC }}$ & $\begin{array}{c}\text { Westinghouse PFBC } \\
\text { (ECAS) }\end{array}$ & $\begin{array}{c}\text { Babcock \& Wilcox } \\
\text { AFBC (TVA) }\end{array}$ \\
\hline $\begin{array}{l}\text { Furnace arrangement, } \\
\text { typical module }\end{array}$ & $\begin{array}{l}\text { Vertical tower } \\
7 \text { stacked beds }\end{array}$ & $\begin{array}{l}\text { Vertical tower } \\
4 \text { stacked beds }\end{array}$ & $\begin{array}{l}\text { Vertical tower - } 3 \\
\text { plus one unstacked }\end{array}$ \\
\hline $\begin{array}{l}\text { Plan area per } M W(e) \\
m^{2}\left(f t^{2}\right)\end{array}$ & $0.054(0.59)$ & $0.17(1.85)$ & $1.80(19.4)$ \\
\hline $\begin{array}{l}\text { Weight per MW(e) } \\
\text { kg (tons) }\end{array}$ & $2019(2.22)$ & $1875(2.06)$ & - \\
\hline $\begin{array}{l}\text { Installed cost-boiler system } \\
\text { only, } \$ / \mathrm{kW}(\mathrm{e})\end{array}$ & $24.1^{a}$ & $24.8^{a}$ & $105^{b}$ \\
\hline $\begin{array}{l}\text { Primary heat transfer } \\
\text { surface material }\end{array}$ & $\begin{array}{l}\text { carbon steel } \\
\text { chrome alloy steel } \\
\text { stainless steel }\end{array}$ & $\begin{array}{l}\text { carbon steel } \\
\text { chrome alloy steel } \\
\text { stainless steel }\end{array}$ & $\begin{array}{c}\text { same as } \\
\text { conventional coal- } \\
\text { fired boiler }\end{array}$ \\
\hline
\end{tabular}

$a_{\text {Mid-1975 dollars }}$

$b_{1978 \text { dollars }}$ 
combustion temperatures and lower $\mathrm{Ca} / \mathrm{S}$ ratios than considered practical for the AFBC. The longer gas residence time in the deeper PFBC beds, in addition to a more favorable chemical equilibrium for sulfur capture with dolomite in pressurized beds, is responsible for this design advantage.

An additional recent study sponsored by DOE found that the limestone consumption cost was a very small part of the plant's cost of electric1ty. 22 On this basis, the effort expended in optimizing the $\mathrm{Ca} / \mathrm{s}$ ratio would not seem justifiable. However, the capital investment associated with the solids handling is rather significant (to be discussed in a later section) warranting that the limestone or dolomite feed not be oversized.

In summary, it is reasonable to assume that a PFBC can operate with a somewhat lower $\mathrm{Ca} / \mathrm{S}$ ratio than an $\mathrm{AFBC}$ to achieve the same sulfur capture. This advantage is somewhat offset by the lower active sorbent content of dolomite.

Hot gas cleanup

Pertinent information on the hot gas cleanup systems envisioned in the PFBC designs is provided in Table 7. Each designer stated that the performance of the systems was yet to be verified. The reasons for the different cost estimates in ECAS are mostly the result of different filter areas per unit volume of gas flow and different assumptions for the flue gas particulate loading. Note that the cost of these systems exceeds that of the furnace modules.

\section{Coal and sorbent metering}

The solids transport method and number of solid injectors per bed are the two most significant design features of the fluidized bed coal and sorbent feed systems since they, to a great extent, determine its cost. Design data for several conceptual systems are summarized in Table 8. Combustion Engineering ${ }^{23}$ specifically discarded the GE AFBC solids feeding choice which introduces the solids into the bed through needles protruding through the walls of the bed. The needles, being 
Table 7. Comparison of PFBC hot gas cleanup systems

\begin{tabular}{|c|c|c|c|c|}
\hline & GE-ECAS & Westinghouse-ECAS & Burns \& Roe & Curtiss-Wright \\
\hline Number of cyclone stages & 2 & 2 & 2 & 2 \\
\hline Granular bec̈ filter & Yes & Yes & Uncertain & Uncertain \\
\hline $\begin{array}{l}\text { Gas velocity through filter } \\
\mathrm{m} / \mathrm{s} \text { (ft/sec) }\end{array}$ & $11.9(39)$ & $22.9(75)$ & - & - \\
\hline $\begin{array}{l}\text { Anticipated particulate load } \\
\text { in dirty gas - } \mathrm{kg} / \mathrm{kg} \text { gas } \\
(\mathrm{gr} / \mathrm{SCF})\end{array}$ & $.0287(15.5)$ & $0.0245(13.3)$ & $0.0165(8.9)$ & - \\
\hline $\begin{array}{l}\text { Anticipated particulate load } \\
\text { in filtered gas } \\
\mathrm{kg} / \mathrm{kg} \text { gas (gr/SCF) }\end{array}$ & unknown & $0.000014(.00742)$ & $0.000043(0.023)$ & $0.000024(0.013)$ \\
\hline $\begin{array}{l}\text { System installed cost } \\
\$ / k W(e)\end{array}$ & 76.3 & 32.6 & - & - \\
\hline
\end{tabular}


Table 8. Summary $O \equiv$ PFBC and AFBC solids feeding designs

\begin{tabular}{|c|c|c|c|c|}
\hline & $\begin{array}{l}\text { GE-ECAS } \\
\text { PFBC }\end{array}$ & $\begin{array}{c}\text { Westinghouse-ECAS } \\
\text { PFBC }\end{array}$ & $\begin{array}{l}\text { GE-ECAS } \\
\text { AFBC }\end{array}$ & $\begin{array}{c}\text { Combustion Engr. } \\
\text { AFBC }\end{array}$ \\
\hline Method of transpert & $\begin{array}{l}\text { Pressurized } \\
\text { injector }\end{array}$ & $\begin{array}{l}\text { Pressurized } \\
\text { injector }\end{array}$ & $\begin{array}{l}\text { Vibrating table } \\
\text { with air assist } \\
\text { at injector }\end{array}$ & $\begin{array}{l}\text { Screw feeder with } \\
\text { air assist }\end{array}$ \\
\hline $\begin{array}{l}\text { Bed area per injector } \\
\mathrm{m}^{2}\left(\mathrm{ft} \mathrm{t}^{2}\right)\end{array}$ & $0.56(6.0)$ & $2.14(23.0)$ & $0.79(8.5)$ & $1.67(18.0)$ \\
\hline Over/under bed feed & $\begin{array}{c}\text { under, through } \\
\text { grid plate }\end{array}$ & $\begin{array}{l}\text { under, through } \\
\text { grid plate }\end{array}$ & $\begin{array}{l}\text { under, thrcugh } \\
\text { injection needles }\end{array}$ & $\begin{array}{l}\text { under, through } \\
\text { grid plate }\end{array}$ \\
\hline System cost $\$ / k W(e)$ & 55.2 & 37.8 & 35.1 & - \\
\hline
\end{tabular}


exposed to the burning materials, are subject to coking and plugging. Note that the pressurized Injector systems are substantially more expensive.

Fluidized Combustion Company ${ }^{24}$ is proposing an overbed spreader for coal and overbed limestone injection. It is claimed that this system is reliable, simple, and reduces the solids crushing requirements. However, introducing the coal at the top of the bed means that some sulfur will be released near the top of the bed and have essentially no opportunity to react with the lime.

The Babcock \& Wilcox design is similar to the Combustion Engineering design except that an injector serves only $0.84 \mathrm{~m}^{2}\left(9.0 \mathrm{ft}^{2}\right)$ of bed area.

The coal metering system proposed in the ECAS PFBC design studies is based on the Petrocarb solids injecting system which has been utilized in the industrial sector for some time. This system consists of a storage bin which receives solids from a larger storage vessel, a lockhopper where the solids are pressurized in batches, and pneumatic, dense phase transport lines. Such a system is currently in use at the National Coal Board PFBC experimental facility in Leatherhead, England. The feed ports enter the bed through the air tuyere plate in most conceptual designs but enter through the sides of the bed in the National Coal Board test unit. The nozzles in this test unit are water-cooled since they are exposed to the hot bed material.

\section{Combustion efficiency}

Combustion efficiency and freeboard burning are fluidized bed parameters which must be considered in the design of the furnace system. PFBC's are envisioned as having higher combustion efficiencies and less freeboard combustion since the beds are deeper. However, both GE and Westinghouse (even with its high temperature bed) considered it necessary to add a carbon burnup cell to their respective PFBC furnace designs to minimize the unburned carbon 1oss. The Burns \& Roe air-cooled PFBC, on the other hand, is proposed to operate at a lower air velocity for which there is evidence of nearly complete combustion in the bed.18 Hence, the carbon burnup cel1 is absent from their PFBC unit. 
The AFBC design of Combustion Engineering, Inc., 23 also includes a carbon burnup cell needed especially for their high superficial velocity $[3.7 \mathrm{~m} / \mathrm{s} .(12 \mathrm{ft} / \mathrm{sec})]$ design. Babcock \& Wilcox ${ }^{25}$ also incorporated the carbon burnup cell in their AFBC design. Final carbon loss is generally anticipated as about $1 \%$ of the fuel heating value.

\section{Overall power plant efficiency}

The predicted efficiencies of the PFBC plants have been included in Table 5 at the beginning of the section. It is apparent that there is some advantage in utilizing the high thermodynamic availability of the energy in hot combustion gas for power generation. The variation between the designs is small, being generally attributable to differences in the assumed losses, different stack gas temperatures, etc.

Brown-Boveri (developer of the Velox boiler) has investigated the effect of the gas turbine inlet temperature on the efficiency of conceptual systems utilizing pressurized oil-fired furnaces. ${ }^{26}$ They found no difference in the efficiency of plants ut1lizing a $430^{\circ} \mathrm{C}\left(806^{\circ} \mathrm{F}\right)$ inlet temperature and plants utilizing a turbine inlet temperature of $880^{\circ} \mathrm{C}\left(1616^{\circ} \mathrm{F}\right)$. The reason for this result is that, in the latter case, the gas leaving the turbine at about $430^{\circ} \mathrm{C}\left(806^{\circ} \mathrm{F}\right)$ wàs necessar11y utilized for feed heating in the steam bottoming cycle in lieu of conventional feed heating. This degraded the steam cycle efficiency enough to nullify the advantage gained in obtaining power from the gas turbine ( $18 \%$ of plant total) in surplus of that needed for the combustion air compressor.

Whether the capital cost associated with the incremental efficiency gain is justifiable is unclear according to the estimates currently available. However, the components required for the PFBC system will require a substantially greater technology advancement relative to the AFBC units currently envisioned.

Estimates for p1ant cost and cost of electricity

The cost estimates from several design studies for the PFBC plants are provided in Table 9, including the major cost estimating assumptions. 
Table 9. PFBC cost estimates and assumptions

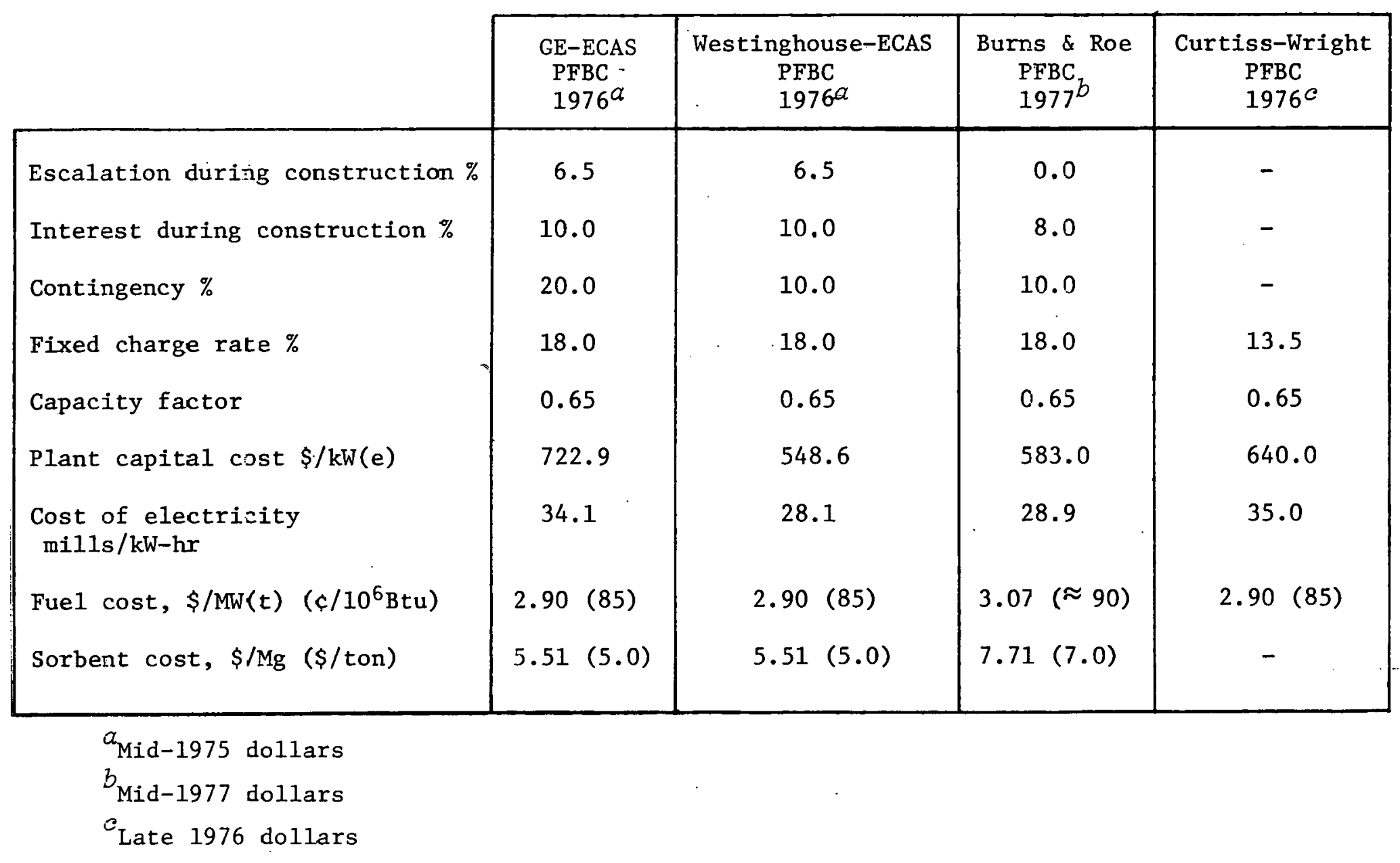


Differing design assumptions concerning gas cleanup and solids handling are primarily responsible for the cost disagreement in the ECAS systems, and it is difficult to estimate which one, if either, is correct. Addition of charges for escalation during construction would bing the Burns \& Roe estimate for their PFBC to probably over $650 \$ / \mathrm{kW}(\mathrm{e})$, considerably higher than the Westinghouse system.

These cost estimates are generally lower than those calculated in recent $A F B C$ design studies and evaluations. It should be noted, however, that the AFBC studies are generally more detailed and, therefore, perhaps more reliable.

Summary of design study survey

In general, the current design studies with cost estimates do not bear out the hoped for advantages of the PFBC. Even with no monetary value placed on the development required and the uncertainty in performance of critical components, the PFBC is not universally seen as providing lower cost electricity. An advantage in fuel economy for the PFBC is concluded in all of the design studies, but capital charges are much more pronounced in their contribution to the cost of electricity than fuel charges. The combined cycle systems utilizing the PFBC to heat most or all of the alr supplied to a gas turbine offer some reliet in gas cleanup costs but are likely to be penalized by higher costs for the heat transfer surface.

It should be noted that the design study participants for the PFBC units expressed the belief that further development work was needed, especially in turbine technology and gas cleanup. Otherwise, the PFBC must be viewed as having development needs similar to those of the AFBC. Such development needs cited by AFBC design teams include:

1. System control and response

2. Combustion efficiency

3. Sulfur capture

4. Tube corrosion/erosion

5. Fuel feeding for large units. 


\section{DELINEATION OF KEY PROBLEMS}

\section{Hot Gas Cleanup}

Forty years of experience with removing particulate matter from hot gas streams flowing into gas turbines indicates that the best that has been achieved with an economically viable system is to reduce the particulate content to around $100 \mathrm{ppm}$, whereas for an acceptable turbine life, the particulate content must be kept below 1 ppm if the turbine inlet temperature is to be in the 816 to $871^{\circ} \mathrm{C}\left(1500\right.$ to $1600^{\circ} \mathrm{F}$ ) range. However, both turbine bucket erosion and deposit problems become less serious as the turbine inlet temperature is reduced, and it appears that if the turbine inlet temperature is kept to, $2538^{\circ} \mathrm{C}\left(1000^{\circ} \mathrm{F}\right)$, a tolerable turbine life can be obtained with an inlet gas particulate content of $100 \mathrm{ppm}$. Thus, the first order of business in establishing the feasibility of a pressurized fluidized bed would be to determine whether the particulate matter emerging from the hot gas cleanup system in the 100-ppm range gives a tolerable turbine erosion and deposit problem.

\section{Coa1 Feed System}

Feeding crushed coal into a furnace operating at 0.3 to $1.0 \mathrm{MPa}$ (3 to $10 \mathrm{~atm}$ ) poses formidable problems that can be investigated in bench tests at a relatively modest cost. Thus, bench tests of various types of equipment suitable for metering and feeding the coal into a pressurized furnace ought to be initiated and pursued vigorously. The imperativeness of adequate development for these systems is typified by operating problems experienced during tests at the Rivesville AFBC system and the Babcock \& Wilcox AFBC.

\section{Lateral Rate of Coal Dispersion from Feed Points}

It is important to know for both atmospheric and pressurized fluidized beds the rate at which coal is dispersed laterally by turbulence in the bed from feed points so that locally rich regions where reducing conditions might prevail can be avolded. These tests are badly needed to establish the appropriate spacing for coal feed points and the depth of bed required between coal feed points and the bottom of 
the boller tube matrix in order to avoid difficulty with serious corrosion of the tubes. These tests must include the effects of the amount of excess air on combustion rates and the development of reducing zones in a fluidized bed. These test should also include the effects of variations in feed port and air tuyere design because details in the geometry of these parts is likely to have a strong influence on the mixing rate.

\section{Effects of Pressure Level on Plant Heat Rate}

The advantage from the standpoint of thermal efficiency of a 1.0$\mathrm{MPa}$ (10-atm) bed as opposed to a supercharged bed at 0.3 to $0.5 \mathrm{MPa}$ (3 to $5 \mathrm{~atm}$ ) or an atmospheric bed needs to be clarified. Information on oil-fired combined cycles indicates that even if the turbine erosion and deposit problems can be solved, the heat rate advantage may not offset the extra pressure drop and capital costs requirements of the hot gas cleanup equipment required for the $1.0-\mathrm{MPa}$ (10-atm) combined cycle plant with a 816 to $871^{\circ} \mathrm{C}\left(1500\right.$ to $\left.1600^{\circ} \mathrm{F}\right)$ turbine inlet temperature.

\section{Effects of Bed Depth on the Performance of Pressurized Fluidized Beds}

There has been no systematic investigation of the effects of bed depth on the performance of pressurized fluidized beds with respect to combustion efficiency and sulfur retention with good control of the amount of excess air, the fuel and limestone compositions, bed temperature and pressure, $\mathrm{Ca} / \mathrm{S}$ ratio, etc. Thus, a set of tests ought to be run to investigate the effects of bed depth on the combustion efficiency and sulfur retention for the full range of variables.

Further, an evaluation of the potenclal benefits of greater bed depth particularly in terms of use of vertical tubes in the bed should be carried out. 


\section{REFERENCES}

1. National Coal Board, Reduction of Atmospheric Pollution - Final Report on Research on Reducing Emission of Sulphur Oxides, Nitrogen Oxides, and Particulates by Using Fluidized Combustion of Coal, Report DHB 060971, prepared for the Environmental Protection Agency, Office of Air Programs (September 1971).

2. National Research Development Corporation, Pressurized Fluidized Bed Combustors, R\&D Report 85, Interim No. 1, prepared for Office of Coal Research, Department of the Interior (1974).

3. H. R. Hoy and A. G. Roberts, "Further Experiments on the PilotScale Pressurized Combustor at Leatherhead, England," Proceedings of the Fluidized Bed Combustion Technology Exchange Workshop, CONF-770447-P-2, Vol. 2 (April 1977).

4. G. J. Vogel et a1., Reduction of Atmospheric Pollution by the Application of Fluidized Bed Combustion and Regeneration of SulfurContaining Additives, Annual Report, July 1973-June 1974, ANL/ES/ CEN-1007 (September 1974).

5. D. A. Furlong and G. L. Wade, "Use of Low Grade Solid Fuels in Gas Turbines," ASME Paper 74-WA/ENER-5, presented at the ASME Winter Annual Meeting, Nov. 18, 1974.

6. Combustion Power Company, Inc., Energy Conversion from Coal Utilizing CPU-400 Technology - Monthly Report for August 1976, FE-1536-M37. (September 1976).

7. W. G. Stevens and A. R. Stetson, Corrosion and Erosion Evaluation of Turbine Materials in an Environment Simulating the CPU-400 Combustor operating on Coal, DOE Report FE/1536-3 (April 1977).

8. S. J. Van Grouw, "Corrosion Studies and High Temperature Filtration," Proceedings of the Fluidized Bed Combustion Technology Exchange Workshop, CONF-770447-P-2, Vol. 2 (April 1977).

9. R. J. Priem, "NASA's Pressurized Fluidized Bed," Proceedings of Fluidized Bed Combustion Technology Exchange Workshop, CONF-770447P-2, Vol. 2 (Apri1 1977).

10. D. L. Keairns et al., "Experimental and Engineering Investigations for the Development of Fluidized Bed Combustion Processes," Proceedings of Fluidized Bed Combustion Technology Exchange Workshop, CONF-770447-P-2, Vo1. 2 (April 1977).

11. S. Moskowitz, "The Curtiss-Wright Pressurized Fluidized Bed Pilot Electric Plant," Proreestings of the Fifth International Conference on Fluidized Bed Combustion, Washington, D.C., Dec. 12-14, 1977.

12. D. H. Broadbent, "Fluidized Bed Combustion - The Grimethorpe Experimental Facility," Proceedings of Fluidized Bed Combustion Technology Exchange Workshop, CONF-770447-P-2, Vol, 2 (April 1977). 
13. A. P. Fraas, personal communfcation regarding meeting at DOE, July 31, 1978, on Selection of a Gas Turbine for the Grimethorpe Facility, Aug. 3, 1978.

14. M. E. Lackey, Summary of the R\&D Effort on Open-Cycle Coal-Fired Gas Turbines, ORNL/TM-6253 (to be published).

15. J. P. Meyer and M. S. Edwards, Survey of Industrial Coal Conversion Equipment Capabilities: High Temperature, High Pressure Gas Purification, ORNL/TM-6072 (June 1978).

16. D. T. Beecher et al., Energy Conversion Alternatives Study, Westinghouse Phase II Final Report, Volume III, Summary and Advanced Steam Plant with Pressurized Fluidized Bed Boilers, NASA CR-134942 (Noyember 1976).

17. J. C. Corman et al., Energy Conversion Altematives Study, General Electric Phase II Final Report, Volume II, Advanced Energy Conversion Systems - Conceptual Designs, Part 1, Analytical Approach, NASA CR-134949 (December 1976).

18. D. H. Brown et a1., Energy Conversion Altematives Study, General Electric Phase II Final Report, Volume II, Advanced Energy Conversion Systems - Conceptual Designs, Part 2, Closed Turbine Cycles, NASA CR-134949 (December 1976).

19. D. A. Huber et al., "Conceptua1 Design of a Coa1 Fueled, Fluid Bed Combined Cycle Plant," presented at Fifth International Conference on Fluidized Bed Combustion, Washington, D.C., December 1977.

20. G. D. Singh and S. Moskowitz, "Economic Feasibility of Coal-Fired Combined Cycle Electric Power Generation Using Pressurized Fluidized Bed Combustion," presented at American Power Conference, Chicago, I11., Stone \& Webster Engineering Corp., 1977.

21. A. P. Fraas et al., "A New Approach to a Fluidized Bed Steam Boiler," Paper No. 76-WA/Pwr-8, presented at the ASME Winter Annual Meeting, December 1976.

22. Conceptual Design of an Atmospheric Fluidized Bed Combustion Electric Power Generating Plant - Executive Summary, Burns \& Roe, Inc. (March 1978).

23. "Preliminary Design Study for a Fluidized Bed Demonstration Unit," Draft, Combustion Engineering, Inc., January 1978.

24. "Preliminary Design and Cost Estimate for an Atmospheric Fluidized Bed Steam Generator," Draft, Fluidized Combustion Company, January 1978.

25. W. A. Hansen, "Conceptual Studies and Preliminary Design of a Fluid Bed Boiler for Service in an Electric Utility," Draft, The Babcock and Wilcox Company, February 1978.

26. Brown Boveri Review, Vol. 62 (July/August 1975). 
ORNL/TM-6633

\section{Internal Distribution}

$\begin{aligned} \text { 1. } & \text { Seymour Alpert } \\ 2 . & \text { T. D. Anderson } \\ 3 . & \text { Harold Beuther } \\ 4 . & \text { C. R. Boston } \\ 5 . & \text { R. A. Bradley } \\ 6 . & \text { H. D. Cochran } \\ 7 . & \text { M. S. Edwards } \\ 8 . & \text { E. C. Fox } \\ 9 . & \text { A. P. Fraas } \\ \text { 10. } & \text { W. Fulkerson } \\ 11 . & \text { W. R. Gambill } \\ 12 . & \text { R. W. Glass } \\ 13 . & \text { T. G. Godfrey } \\ \text { 14-28. } & \text { R. L. Graves } \\ 29 . & \text { W. L. Greenstreet } \\ 30 . & \text { E. C. Hise } \\ 31 . & \text { R. S. Holcomb } \\ 32 . & \text { J. M. Holmes } \\ 33 . & \text { Carol Oen } \\ \text { 34-48. } & \text { J. E. Jones, Jr. } \\ 49 . & \text { R. E. Kuhlmann } \\ \text { 50-54. } & \text { M. E. Lackey }\end{aligned}$

55. R. E. MacPherson

56. L. E. McNeese

57. J. P. Meyer

58. J. P. Nichols

59. T. W. Pickel

60. H. Postma

61. M. W. Rosenthal

62. G. Samuels

63. Marion Semchyshen

64. M. Simon-Tov

65. C. B. Smith

66. I. Spiewak

67. Carl Streed

68. H. W. Sternberg

69. J. F. Thomas

70. H. E. Trammel1

71. D. B. Trauger

72-73. Central Research Library

74. Document Reference Section

75. ORNL Patent Section

76-79. Laboratory Records Department

80. Laboratory Records, ORNL (RC)

\section{External Distribution}

81. J. T. Bartis, Systems Engineering, Department of Energy, C-164 Germantown, Washington, D.C. 20545

82. Lee E. Brecher, Kentucky Center for Energy Research Laboratory, Iruil Works Pike, P.0. Bux 13015, Lexington, KY 40583

83. R. W. Cantre11, Tennessee Valley Authority, 400 Commerce Avenue, Knoxville, TN 37902

84. Russ Core11, Combustion Engineering Power Systems, Combustion Engineering, Inc., 1000 Prospect Hill Road, Windsor, CT 06095

85. Roger Cunningham, Kentucky Center for Energy Research, Iron Works Pike, P.0. Box 13015, Lexington, KY 40583

86. E. D. Daugherty, Tennessee Valley Authority, 1340 Commerce Union Bank Building, Chattanooga, TN 37401

87. David Drake, Kentucky Department of Energy, P.0. Box 11888, Lexington, . KY 40578

88. R. H. Dunham, Tennessee Valley Authority, 400 Commerce Avenue, Knoxville, TN 37902

89. Shelton Ehrlich, Fossil Fuel Power Plants Department, Electric Power Research Institute, P.0. Box 10412, Palo Alto, CA 94303

90. H. L. Falkenberry, Tennessee Valley Authority, 1345 Commerce Union Bank Bullding, Chattanooga, TN 37401 
91. S. I. Freedman, Asst. Director for Combustion and Advanced Power, E-178 Germantown, Washington, DC 20545

92. Robert L. Gamble, Foster-Wheeler, 110 South Orange Avenue, Livingston, NJ 07039

93. J. F. Geffken, Fossil Fuel Utilization, Department of Energy, E-178 Germantown, Washington, DC 20545

94. J. L. Golden, Tennessee Valley Authority, 400 Commerce Avenue, Knoxville, TN 37902

95. Walt Hanson, Babcock \& Wilcox, Inc., Fossil Power Generation Division, P.O. Box 315, Barberton, OH 44203

96. K. M. Haythorne, Department of Energy, Oak Ridge Operations, Oak Ridge, TN 37830

97-100. D. Bruce Henschel, Advanced Process Branch, U.S. Environmental Protection Agency, Research Triangle Park, NC 27711

101. G. A. Hollinden, 'lennessee Valley Authority, 470 Commerce Union Bank Bullding, Chat tanooga, TN 37401

102. Bill Howe, Electric Power Research Institute, 3412 Hillview Avenue, P.0. Box 10412, Palo Alto, CA 94303

103. J. A. Hudson, Tennessee Valley Authority, 400 Commerce Avenue, Knoxville, TN 37902

104. Dr. Richard Johnson, University of Tenn. at Chattanooga, School of Engineering, 222 Grote Hall, Chattanooga, TN 37402

105. R. N. Kennedy, Tennessee Valley Authority, 415 Power Building, Chat tanooga, TN 37401

106. J. A. Lenhard, Department of Energy, Oak Ridge Operations, Oak Ridge, TN 37830

107. E. Lievens, Department of Energy, Director of Division of Fossil Fuel Utilization, E-178 Germantown, Washington, DC 20545

108-122. R. L. Lumpkin, Tennessee Valley Authority, 440 Commerce Union Bank Building, Chattanooga, TN 37401

123. Terry E. Lund, Electric Power Research Institute, 3412 Hillview Avenue, P.O. Box 10412, Palo Alto, CA 94303

124. M. J. Mayfield, Tennessee Valley Authority, 440 Commerce Union Bank Building, Chattanooga, TN 37401

125. W. G. Miller, Tennessee Valley Authority, 330 Chestnut Street Towers, II, Chattanooga, TN 37401

126. H. G. Moore, Tennessee Valley Authority, 268401 Building, Chat tanooga, TN 37401

127. H. G. Parris, Tennessee Valley Auchority, 500A Chestnut Street Towers, II, Chattanooga, TN 37401

128. D. R. Patterson, Tennessee Valley Authority, 400 Commerce Avenue, Knoxville, TN 37902

129. Dr. Fred N. Peebles, Dean of Engineering, University of Tennessee, 124 Perkins Hall, Knoxville, TN 37916

130. K. E. Phillips, Combustion Power Company, 1346 Willow Road, Menlo Park, CA 94025

131. A. A. Pitrolo, Department of Energy, Morgantown Energy Technology Center, P.0. Box 880, Morgantown, WV 26505

132. C. M. Podeweltz, Tennessee Valley Authority, 1360 Commerce Union Bank Bullding, Chattanooga, TN 37401

133. C. J. Powell, Tennessee Valley Authority, 1345 Commerce Union Bank Building, Chattanooga, TN 37401 
134. L: L. Radcliffe, Department of Energy, Oak Ridge Operations, Oak Ridge, TN 37830

135. J. T. Reese, Tennessee Valley Authority, 705 Edney Building, Chat tanooga, TN 37401

136. V. C. Shattuck, Tennessee Valley Authority, 705 Edney Building, Chat tanooga, TN 37401

137. G. R. Siege1, Tennessee Valley Authority, 1360 Commerce Union Bank Building, Chattanooga, TN 37401

138. George Weth, Department of Energy, E-178 Germantown, Washington, DC 20545

139. J. H. Williams, Tennessee Valley Authority, 1300 Commerce Union Bank Bullding, Chattanooga, TN 37401

140. John S. Wilson, Department of Energy, Morgantown Energy Techno1ogy Center, P.0. Box 880, Morgantown, WV 26504

141. Kurt Yeager, Electric Power Research Institute, 3412 Hillview Avenue, P.0. Box 10412, Palo Alto, CA 94303

142-168. Technical Information Center, Oak Ridge, Tn. 37830 